\title{
Chapter 6: Charity, Mother of Allegory
}

\author{
Breastfeeding as "Other Speech"
}

This chapter explores the visual tradition of lactation imagery that eventually gave Pero and Cimon their particular resonance as Roman Charity. I argue that the embodiment of breastfeeding women in the arts can be more fully understood against the backdrop of ancient rhetorical theories of allegorization and the emergence of patriarchal kinship structures. The exclusion of women from the public sphere was necessary for images of breastfeeding women to signify ancient "piety" and Catholic "charity." Also, in order to assume such symbolic significance, images of lactation had a decidedly non-maternal bent. Milk-relations in the arts only rarely depicted a mother and her child - with the exception of the Virgin Mary and her son, perhaps, but this was a very special mother nursing a very special son whose neediness came to represent all of suffering mankind. With the emergence of the Madonna Lactans and representations of Charity in the fourteenth century, the lactating breast became the object of spiritual desire. In the Renaissance, when breastfeeding imagery acquired secular connotations, the spiritual breast had to compete for meaning with representations of wet-nurses, lactating goddesses and eroticized mythological creatures. In the Baroque, the motif of Pero and Cimon appropriated earlier meanings of the charitable breast, but also provided for ironic distance through a deliberate eroticization of the imagery. In the eighteenth century, the incestuous encounter between the daughter who breastfed her father came to signify the perversion of kinship relations under the ancien régime.

Since Roman antiquity, the allegorization and deification of "pietas" was associated with the stories of Pero and Cimon and of the daughter who breastfed her mother. Other than Valerius Maximus, who recounts both anecdotes as examples of filial piety, Pliny the Elder mentions in his Natural History (77 СЕ) that in the second century BCE, a column was erected to commemorate the Roman daughter who breastfed her mother in prison. This column was 


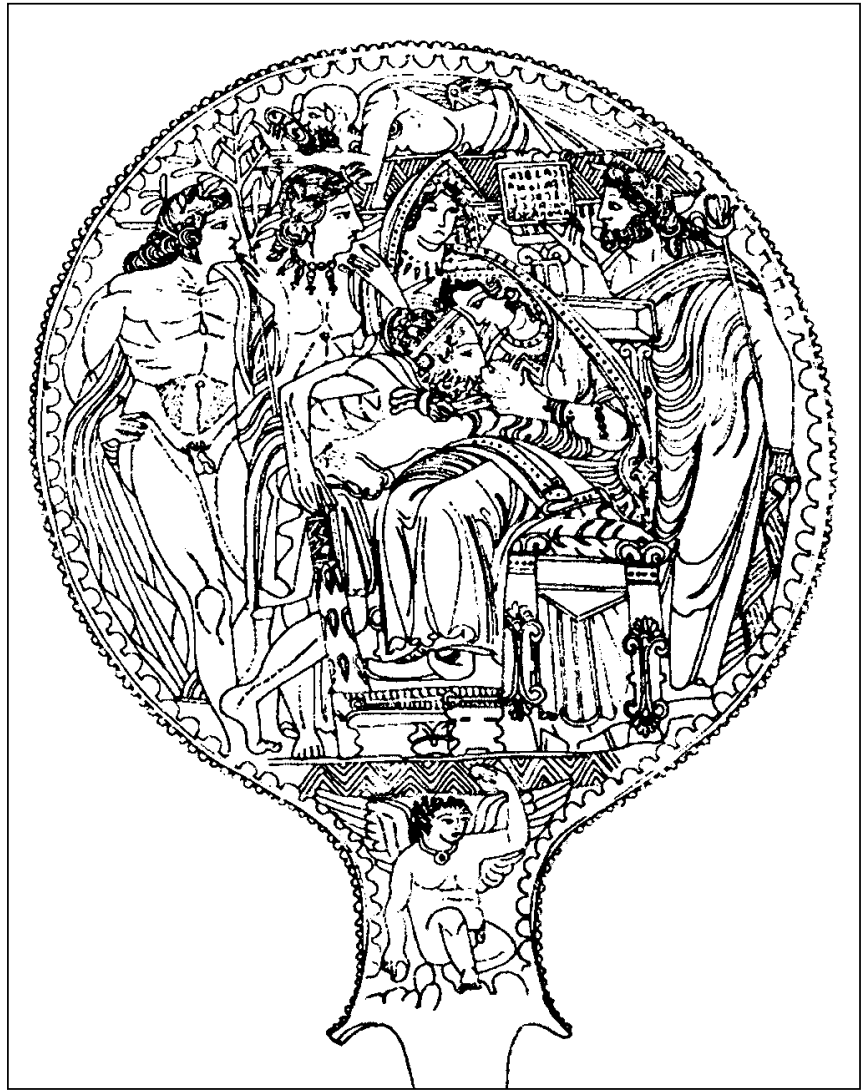

Figure 6.1: Juno Nursing Hercules as a Grown Man, 5th-4th c. BCE, Drawing of an Etruscan Mirror

dedicated to the goddess of piety. More than a century later, Sextus Pompeius Festus refers to the same story in his dictionary On the Significance of Words (ca. $200 \mathrm{CE}$ ), albeit exchanging the mother for the father. He explains the concept of "piety" by referring to the "woman who secretly breastfed her father with the milk of her breasts." At the same time, and somewhat incongruously, Festus declares that piety, in its allegorized form, was worshipped as a goddess: "The Romans honored Piety as they honored the other gods." In his view, humble and self-debasing Pero had become the embodiment, symbol, and content of "piety" itself.

Already in pre-classical antiquity, nursing deities were frequently represented. In Cypriot art of the archaic period, kourotrophoi were statues of mostly female caretakers, often shown in the act of breastfeeding infants. ${ }^{2}$ Kourotrophoi were imagined to turn mortals into demigods through the nourishment 
they provided. Also nymphs could fulfill this function on occasion, according to Virgil's account of Aenaes. Kourotrophoi were imagined to be virgins, which may have accounted for the magic qualities of their milk. According to Theodora Hadzisteliou Price, "the sacramental act of nursing [becomes] symbolic of divine adoption, protection, or initiation as a means to divinity." Wild animals or hybrid creatures such as centaurs and satyrs could also, on occasion, confer special powers through their milk. Harpalyce, a protagonist in one of Hyginus's Fables, became a mighty warrior after being raised by heifers and mares. ${ }^{4}$ This story illustrates that not only male but also female infants could benefit from the exceptional qualities of non-maternal, non-human milk.

The theme of a Greek hero's sacramental nursing may have derived from earlier Egyptian cults, according to which Ishtoar, Nehbet, and Isis breastfed kings and pharaohs. Isis, in particular, is sometimes shown to nurse her son Horus as a grown youth, in an image that may have influenced Etruscan representations of Hera nursing Hercules as a bearded man. ${ }^{5}$ In Italian versions of the myth, Hera does not create the milky way after refusing to nurse Zeus's bastard son and spraying her milk into the universe, but willingly confers immortality on him through an act of ritual breastfeeding (Figure 6.1). ${ }^{6}$ In contrast to Greek art, pre-classical Roman nursing scenes in Italy usually involve a mother and her infant, although starting in the fifth century вСE, kourotrophoi also appear. In classical Greek and Roman art, breastfeeding is no longer something in which a civilized mother would engage. Nursing belongs to the world of goddesses, animals, and barbarians, who foster cross-species infants to form unlikely bonds of affiliation, fosterage, and protection. Human mothers shown in the act of nourishing their own children are marked as social inferiors and colonized others, while wet nurses are often shown past the age of breastfeeding.7 Maximus's twin anecdotes about the pious daughters who nurse their mother and father, respectively, participate in this visual and religious universe in which the depiction of breastfeeding stresses ritual or symbolic, not biological, maternity. As already mentioned, Festus's dictionary shows how in the early third century CE, Pero's sacrificial act of breastfeeding had become the very hallmark of "piety." It suggests that worship of lactating goddesses also survived, couched as veneration for this female virtue.

With the Christianization of the empire, a new development began to take place, which attributed greater significance to mother-son relationships in the depiction of nursing. Two fourth-century bronze medallions show how Christian empresses Helena and Fausta, mother and wife of Emperor Constantine (272-337 CE), respectively, appropriated earlier strands of meaning associated with lactation imagery: piety and female (divine) authority. The coin from 325 CE featuring Helena depicts on its reverse side a woman holding a child on her left arm in the manner of Isis nursing Horus; with her right hand, she offers an apple to another child. This image resembles later representations 


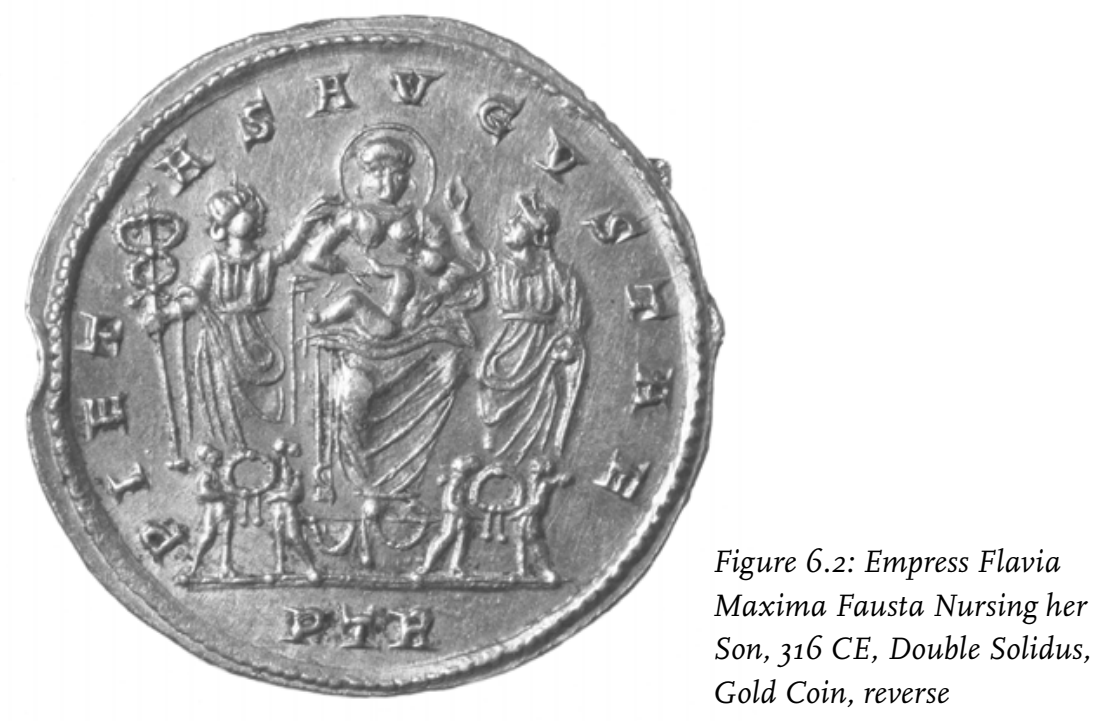

of the Hodegetria, the Byzantine icon of the Virgin and Child. The inscription reads "Pietas Augustes." At about the same time, coins of Empress Fausta show her enthroned and in the act of breastfeeding one or both of her sons (Figure 6.2). Again the intention was to promote the concept of imperial "piety," as the accompanying inscriptions make clear. ${ }^{8}$ Piety, which earlier had been personified by Pero, an outcast who dared to defy imperial justice by nourishing her imprisoned father with the milk of her breasts, now became an attribute of Christian imperial rule. On Helena's and Fausta's medals, "piety" is personified as a figure of maternal authority denoting abundance and generosity, transferring special powers onto her son and ruler.

While a certain ambiguity and love of paradox can be detected in Festus's dictionary, which identifies "piety" as both goddess and self-sacrificing Pero, the contradiction is resolved on those medals. Helena and Fausta gave breastfeeding a new meaning by associating it with maternal authority and imperial largesse, of which the coins that bore their imprint were themselves sign and symbol. This transformation was possible only after visual representations of Pero and Cimon had gone out of fashion. The only remaining ancient wall paintings of the motif date to the first century CE (Figure 4.1), which suggests that in early fourth-century art, breastfeeding as piety was ready to assume new semantic connotations.

Isis, Cybele, Diana of Ephesus, Juno, Vesta, and Tellus Mater - all powerful maternal deities - were still being venerated in various parts of the Roman Empire when Helena and Fausta adopted lactation imagery for their political purposes. ${ }^{9}$ Also, the cult of the Virgin Mary was rapidly spreading. The medallions of Helena and Fausta can thus be seen as an attempt to appropriate and 
possibly monopolize the religious significance of breastfeeding imagery. Just as pagan maternal deities confer special qualities onto their nurslings, Helena and Fausta seem to be lending legitimacy and quasi-divine power to their sons through their milk. However, the strategy of the two first Christian empresses to promote images of breastfeeding as signs of imperial power and abundance did not win out, as worship for the Virgin Mary came to eclipse their visual rhetoric.

Historians are still debating whether the cult of Isis, usually shown in the act of breastfeeding her son Horus (later Harpokrates), might have inspired veneration for the Madonna Lactans, especially since the first known representation of the nursing Madonna is a fourth- or fifth-century Coptic image (Figure 6.3). ${ }^{10}$ Images of the nursing Virgin, however, may have developed independently of the cult of Isis. Third-century wall paintings in the catacombs of Priscilla show a breastfeeding woman, whom some art historians believe to be Mary and her son. ${ }^{11}$ This image remained unique in early Christian Italy, however. The Virgin Mary differed from pagan goddesses in that

Figure 6.3: Madonna Lactans or Tombstone of a Young Woman, $4_{\text {th-5th century CE, Egyptian }}$

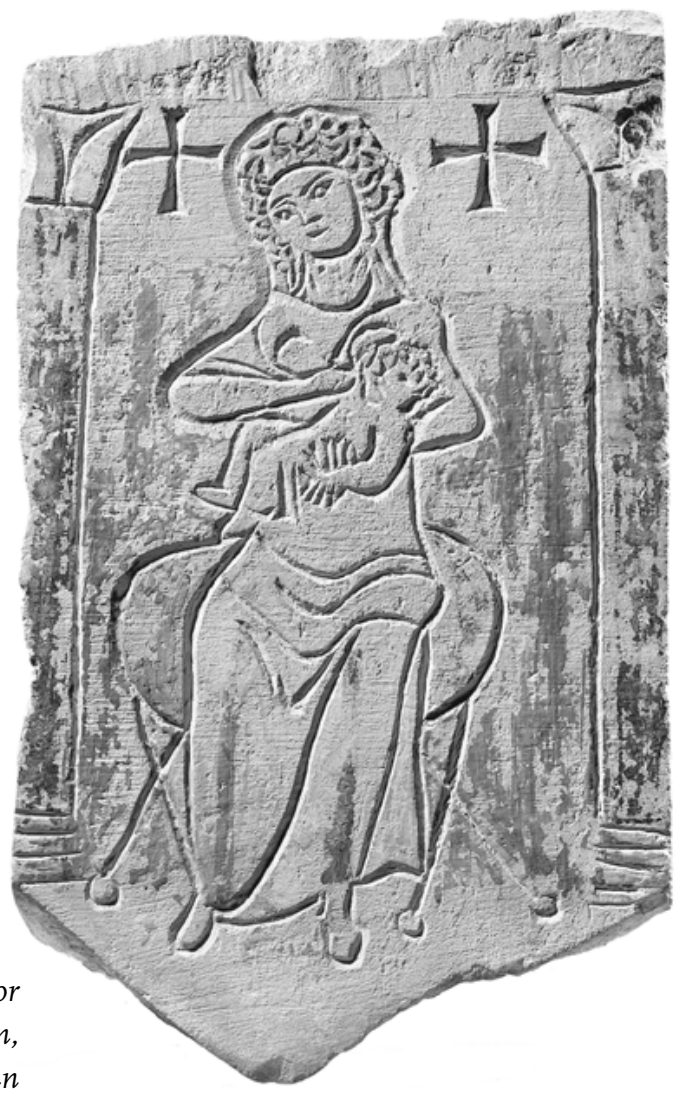


she rendered her son fully human through her milk - she did not confer any divine qualities on him. ${ }^{12}$

In the Byzantine Empire, the development of the cult of the Virgin Mary took a different turn, perhaps due to the co-optation of breastfeeding imagery by Empresses Helena and Fausta, or because of its dangerous proximity to pagan fertility cults. Elevated to the status of "Theotokos" [God-bearer, not mother of God] at the Council of Ephesus in 431, the Virgin Mary came to be worshipped as a rather stern motherly figure. Mary's more tender, maternal feelings for Christ developed only gradually throughout the Byzantine period, as measured by representations of the Hodegetria in the arts. ${ }^{13}$ In Byzantine art, she would only rarely be depicted as nursing (Galaktotrophousa) before the seventeenth or eighteenth centuries. ${ }^{14}$ One early example consists of Theotokos the Milk-Giver from the Hilander Monastery on Mount Athos, Greece (6th century). In Italy, to my knowledge, the earliest representation after antiquity dates from 1270 in Santa Lucia alle Valve in Matera. ${ }^{15}$ By and large, the iconography of the Madonna Lactans was invented or reinvented in fourteenth-century Tuscany, where her imagery developed in tandem with Charity, both of which enjoyed tremendous popularity. ${ }^{16}$ This happened roughly 1000 years after the catacombs of Priscilla were decorated with what might have been the very first artistic rendering of the nursing Virgin, and 800 years after at least in two instances, Coptic and Greek Christians chose to worship her in this manner.

The ascent of lactation imagery to allegorical status in antiquity and early Christianity happened within the context of contemporary theories of allegorization and the construction of kinship as patrilineal in ancient Greece and Rome. Both phenomena, that is, the rhetoric of female embodiment with its emphasis on milk-exchange and the invention of agnatic kinship, have to be seen in the context of an oratorical culture that denied women their own voice. As interlocking mechanisms of exclusion, the codification of patriarchal kinship and the construction of a male sphere of politics worked hand in hand. Legislation about patriarchal family structures, inheritance, and belonging was issued by men who made public use of their voices and who defined the transmission of paternal blood as the basis for their hierarchical vision of family relations. ${ }^{17}$ In this context, the promiscuous sharing of maternal milk between goddesses, empresses, hybrid creatures, even pious daughters and their - mostly male - recipients in the arts and literature served as a reminder of alternative, and possibly prior, ways of defining kinship based on care.

As allegorical embodiments, representations of women found their way back into the public sphere - as mute and spectral figures, lamenting and re-enacting their own exclusion. Ancient Greek oratory deemed female figures of speech useful for the illustration of abstract concepts and for the signification of places of origin. Interestingly, Demetrius of Phalerum (3rd century вСЕ) 
imagines such female personifications to address reproaches to the audience - one wonders what motives he envisioned for their complaints ${ }^{38}$ In his treatise On Style, he praises allegories for "shrouding” one's words in ambiguity, aesthetic appeal, and complexity, since "any darkly-hinting expression is more terror striking, and its import is variously conjectured ... by different hearers." He likens allegories to fanciful clothes, insofar as "things that are clear and plain are apt to be despised, just like men when stripped of their garment." ${ }^{\prime 9}$

In Roman rhetoric, allegories continued to be embraced for their functions to "conjecture" meaning, to arouse "suspicion" and "doubt," and to lend female figures an outlet for complaints. ${ }^{20}$ As their Greek etymological meaning suggests, they were regarded as a kind of "other speech," as alien, but imaginative and impressive, ways of addressing an audience, capable of producing strong affects. ${ }^{21}$ Cicero (106-43 BCE) defines the ventriloquizing of emotions of "children, women, nations, and even of voiceless things" as the prime function of allegorical impersonations, which an attorney would use to arouse pity on behalf of his clients. Such "fictitious speeches" might conjure up "the voice and feelings of the unhappy victims" in the mind of a judge, moved to pity by the employment of "enargeia," i.e., the vividness of the orator's description. ${ }^{22}$ The same effect would not at all be achieved by the victims' direct representation of their suffering in a public sphere governed by the exclusion of women and slaves. The anonymous author of Rhetoric: for Herennius (са. 90 вСE) states unambiguously that rhetorical forms of embodiment work only insofar as the persons to whom they refer - such as women - are absent, excluded, or incapacitated:

"Personification consists in representing an absent person as present, or in making a mute thing or one lacking form articulate, and attributing to it a definite form and a language of certain behavior appropriate to its character ... Personification may be applied to a variety of things, mute and inanimate. It is most useful in the ... Appeal to Pity."23

The Rhetoric thus claims that it is the very exclusion of those absent persons that arouses pity, rather than any attributes they might acquire as personifications. Quintilian (35-100 CE), finally, likens allegories to inversion, illusion, and irony and lists the rhetorical work they are apt to perform as "prosopopeia (personification), visions (phantasia), illustratio, and evidentia (enargeia)."24 As Theresa Kelley states, Quintilian endowed allegories with the subversive effect of disturbing the "ordinary expectations that outward appearances might accurately convey meaning." In his view, visual allegories thrive on multiple and complex relationships they establish between their signifiers and various referents. Eventually, allegories transform into enigmas or riddles, following their "logical angle of repose as ... [figures] of irony or illusion."25

Quintilian's definition of allegory as well as the concept of personification proposed by the author of Rhetoric: for Herennius align perfectly with 


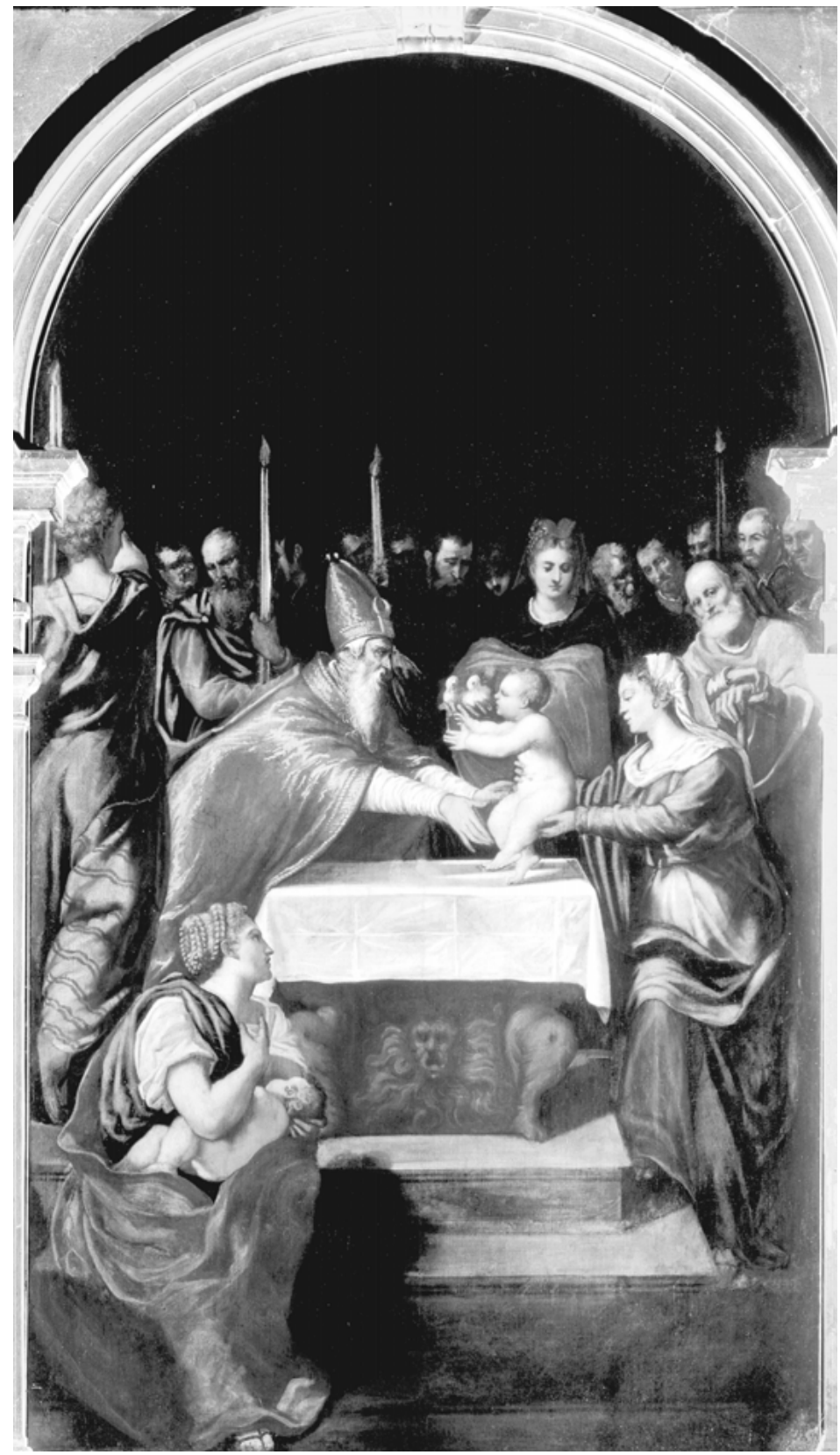

Figure 6.4: Tintoretto, The Circumcision of Christ, 1550-55 
Maximus's narrative employment of Pero as central figure of filial piety. As the Rhetoric prescribes, the breastfeeding daughter is quintessentially pitiful, doubly silenced as both an outsider (Greek) and a woman. Instead of speaking, she is forced to take recourse to a most humble body language in attempting to achieve her father's survival and release from prison. Quintilian's emphasis on visual allegories' multiple, competing referents resonates with the irony, moral ambiguity, and enigmatic character of Maximus's anecdote about Pero and Cimon, which circulated as a riddle about kinship relations since the eleventh century. Moreover, Maximus frames his story as ekphrasis, describing the "riveting" and "amazing" effects of its artistic rendering and pointing to the painting's force in re-presenting the father-daughter couple to the viewer's eyes as if "in those silent outlines of limbs they see living and breathing bodies." 6 Here the eroticized or sensationalist language seems to defy the explicit purpose of the story, namely, to illustrate "filial piety." Instead, Maximus's readers are left with a desire to see those "silent outlines of limbs" - in their nudity, one would assume - as well as Pero's and Cimon's "breathing bodies." The gap, or semantic antagonism between the viewer's voyeuristic desire to witness an erotic and incestuous exchange of body fluids and its alleged moral, didactic meaning, produces irony. Such perversion of intent can, perhaps, explain the immense fortune the iconography enjoyed in first-century art and again since the Renaissance.

With the emergence of Christianity, new views on allegories emerged. Especially since Saint Ambrose's contributions to biblical exegesis, the emphasis was on allegorical interpretations rather than the invention or analysis of rhetorical figures of speech. ${ }^{27}$ According to Ambrose, meaningful connections between the Old and New Testament could only be established by mapping events and persons from Jewish Scripture onto the gospels in the form of pre-figuration and fulfillment. ${ }^{28}$ Such a figurative approach led to the invention of a new type of causality, which collapsed different events evolving in historical time before and after the advent of Christ into the ever-present truth of divine revelation by presenting Moses as a pre-figuration of Jesus, for example, or viewing Mary as the redeemer of Eve. An illustration of this method can be found in Tintoretto's decoration of the Scuola Grande di San Rocco, which establishes multiple visual connections between the gospels and the Old Testament. Not only does Tintoretto stress Jesus's Jewish identity in his painting of The Circumcision of Christ, but he also emphasizes Charity as an over-arching concept of his decorative program, which thematically connects central events such as Moses Striking the Rock, Elisha Multiplying the Bread, The Baptism of Christ, and Christ's Multiplication of Bread and Fish. ${ }^{29}$ In all of these paintings - and several others as well - breastfeeding women appear as both allegories and narrative elements to signify the eternal truth of charity as the ultimate aim of Catholicism and the history of redemption (Figure 6.4)..$^{\circ}$ 


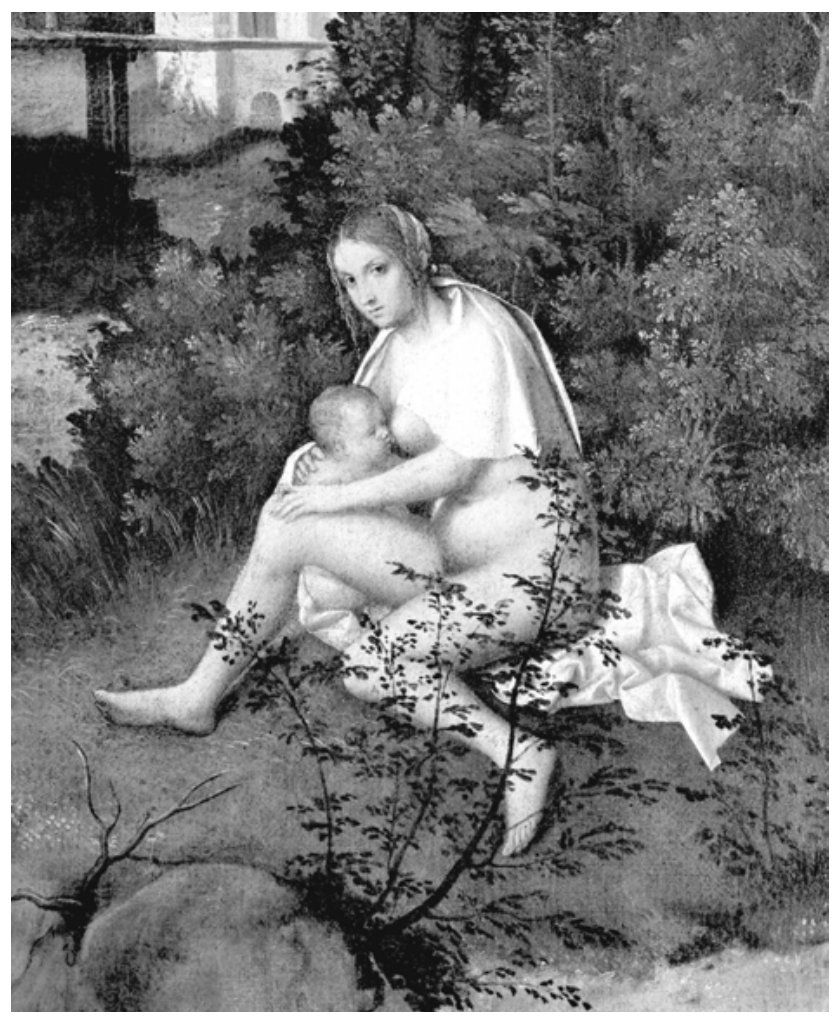

Figure 6.5: Giorgione, Tempest, 1508, Detail

In medieval rhetoric, such overlay of figurative interpretations of existing texts was called "veiling." Allegoresis became the "integumentum" [veil] through which the original meaning of an ancient or biblical text was to be glimpsed. In Renaissance and German Reformation art, veils of allegory were sometimes depicted with great effect and virtuosity, especially when employed to mark nude women as breastfeeding Charities. In Giorgione's Tempest (1508), for example, the veil that covers the nursing woman's shoulders, but not much else, amplifies the riddle-like nature of this painting (Figure 6.5). Through this veil that reveals more than it hides, Giorgione presents his breastfeeding Charity as allegory and figure of desire. Sometimes identified as a portraitcover itself, the painting draws attention to the semantic paradox established by defining the act of veiling or covering as a method of seeking insights and truth.

Lucas Cranach the Elder (1472-1553), a friend of Martin Luther (1483-1546), adopted a similar device for expressing his critical stance vis-à-vis the medieval method of allegoresis, especially when applied to the visual arts. In line 
with the reformers' insistence that Scripture be read "literally," he produced numerous representations of Charity, each one unnecessarily and shockingly naked and embellished with a veil of finely woven lace (Figure 6.6). The artful transparency of Cranach's veils highlights that allegorical embodiments can - and should - become their own subject matter. Cranach's beautiful breastfeeding nudes problematize, just like Giorgione's enigmatic Tempest, not only the theological meaning of charity, but also the very work of allegorical representation. The women's nakedness acquires symbolic meaning in and of itself, overwhelming the viewer with the promise of literal truth. That such knowledge and revelation should be visually represented in the form of an

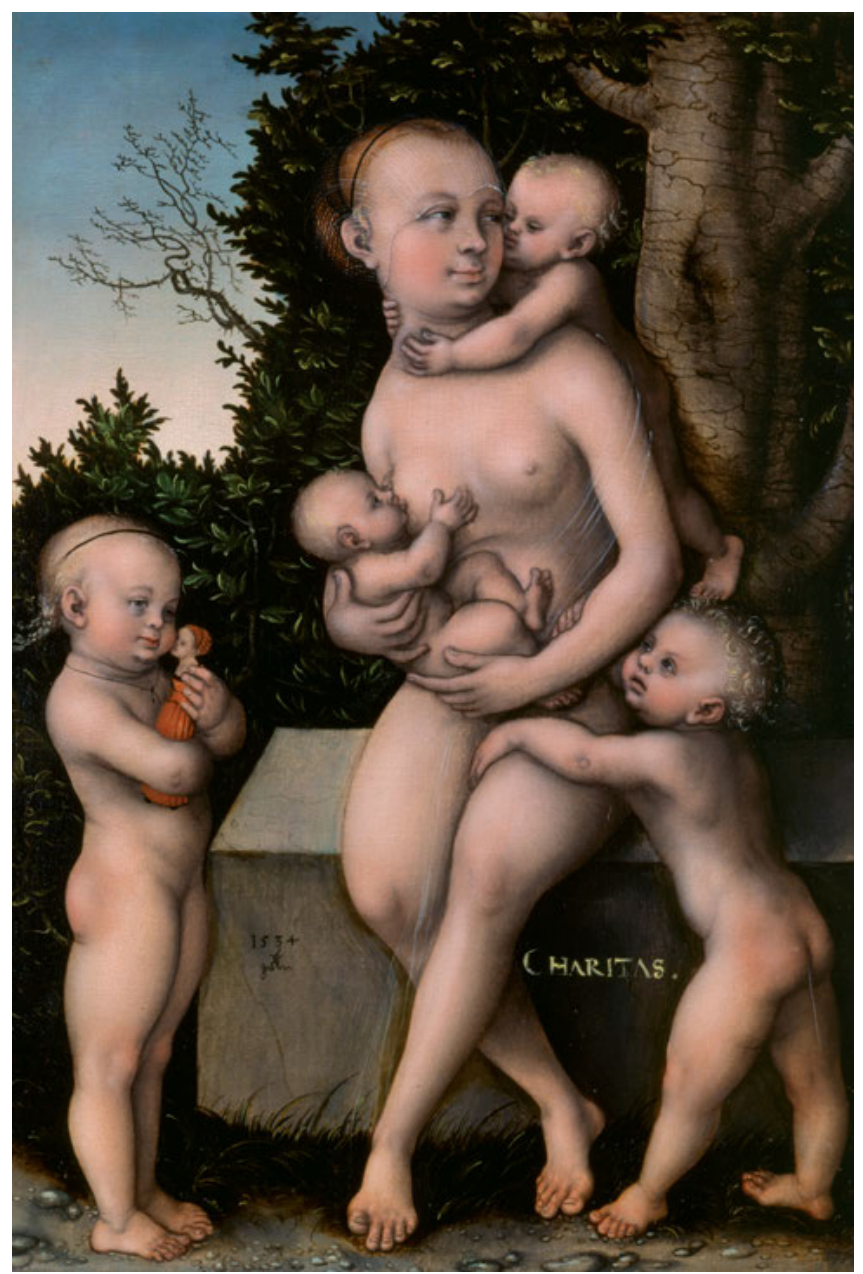

Figure 6.6: Lucas Cranach the Elder, Charity, 1534 
erotic nude exemplifies the dilemma of Reformation artists, caught between the new demands for unambiguous representation and the figurative nature of contemporary art. ${ }^{31}$

As mentioned earlier, the gendered aspects of ancient allegory and medieval allegoresis are causally related to the exclusion of women from the signifying scene since antiquity, i.e., the discourses of philosophy, medicine, and law that feminist theorists have sometimes called "phallogocentric." 32 The fact that breastfeeding imagery in particular acquired allegorical status might be related to the definition of paternal blood in ancient Greek medicine. Concocted to semen, male blood was viewed by Aristotle as the only generative fluid that truly mattered in the process of conception. Women were thought to contribute nourishing matter. ${ }^{33}$ Following Aristotle's mapping of "active" and "passive" principles onto gendered bodies in the process of generation, Plato claimed that any mother was nothing but a nurse, interchangeable in the functions she provided. Her main role was to offer a hollow space within which materialization took place but which in and of itself did not participate in the form- and life-giving process it harbored. ${ }^{34}$ Carrying the mother's exclusion to an extreme, even matter was no longer associated with the feminine but was declared to be unintelligible to the human mind and quasi non-existent unless shaped by the signifying, dialectic encounter with the male. 35

Contemporary Roman culture made its own contribution to the fiction of motherless kinship, supplementing Greek medicine and metaphysics with the legal definition of family as strictly agnatic (patrilineal) ${ }^{6}$ Children were related to their mothers only according to the law of nature, which carried no consequence in terms of inheritance in a public court of law. Again, paternal blood was viewed as the essence and conveyor belt of everything that mattered in the process of generation, the originating principle of all forms, qualities, and properties. Only fathers had true heirs.

The quasi-mystical enhancement of paternal seed in classical Greek philosophy and Roman legal discourse, and the concomitant debasement of pregnancy and nursing, stand in an interesting contrast to the proliferation of kourotrophoi in the archaic period and their pronounced emphasis on milk-exchange. The representation of lactating goddesses or divine wet-nurses in the visual arts often seems to entail an anti-patriarchal view of kinship, such as when Hera nurses Heracles on Etruscan mirrors to adopt him ritually and render him immortal. The fact that he is a grown man emphasizes the fictive or, better, voluntary nature of the kinship bond thus created, i.e., the absence of any sperm-oriented "biological" connection. ${ }^{37}$ Outside the Greco-Roman world, such alternative milk-based models of belonging survived until the early modern period and beyond..$^{8}$

The "other speech" of allegory thus seems to coalesce around the theme of kinship and the kinds of activities and essences that establish meaningful 
relationships between people and words. Lactation imagery, in particular, constitutes a powerful counter-discourse to the hierarchies and exclusions in law and philosophy. "Piety," defined by Festus, subverts prevailing notions of patrilineal kinship in her embodiment as Pero, who in nursing her own father reverses the generational trajectory, returning milk for blood. "Piety" signified as imperial largesse, and configured as Helena and Fausta nursing their sons, supplants a story of patriarchal origins based on sex and birth with a matriarchal principle based on care. The non-verbal, visual, and figurative form of "piety," allegorized through maternal body language, constitutes its own referent. That is, the very meaning of piety consists of signifying and validating extra-legal relationships of care and belonging that exists outside the boundaries of public discourse.

Allegorized piety and lactating goddesses resemble each other in emphasizing breast milk as a reproductive fluid of prime cultural significance, fertile in its capacity to designate meaningful relationships. In the Middle Ages, the reciprocal relationship between breastfeeding as divine attribute and symbol of abstract moral significance reappears in the guise of the Madonna Lactans and Charity as Christianity's most important virtue. The Virgin Mary created "true" kinship with Christ by breastfeeding him, passing on her - human flesh and qualities to God in an interesting reverse gesture vis-à-vis Isis, who rendered Horus divine. Charity stepped in for ancient "piety," recreating the split between humility and divinity that Festus recorded in his dictionary On the Significance of Words. Both phenomena, the promotion of the Virgin Mary from "God-bearer" to humble, nursing mother of God and the view of Charity as a woman breastfeeding more than one infant, thrive on the displacement and re-evocation of mothering. While Mary adopts all of Christianity into her powers of intercession by nursing Christ, in and through whom believers enjoy access to redemption, Charity qualifies as love of one's neighbor precisely because she takes care of strangers. ${ }^{39}$

The Madonna Lactans and the representation of Charity as a breastfeeding woman developed in tandem in the first half of the fourteenth century. Robert Freyhan has shown how a century prior, artists depicting Charity had not yet settled on lactation imagery but were experimenting with different attributes such as cornucopias and flames. While cornucopias were of ancient extraction, signifying abundance, flames were a contemporary invention. They represented Charity's burning heart and desire, thought to be inseparable from the love of God, especially since twelfth- and thirteenth-century mystics collapsed Saint Augustine's distinction between charity and desire. $4^{\circ}$ Max Seidel argues that in twelfth- and thirteenth-century theological discourse, especially in commentaries on the Song of Songs and other mystical writings, multiple associations emerged between the breasts of Charity, Ecclesia [Church], and the Virgin Mary. In the visual arts, Giovanni Pisano was the first to represent Charity, also 


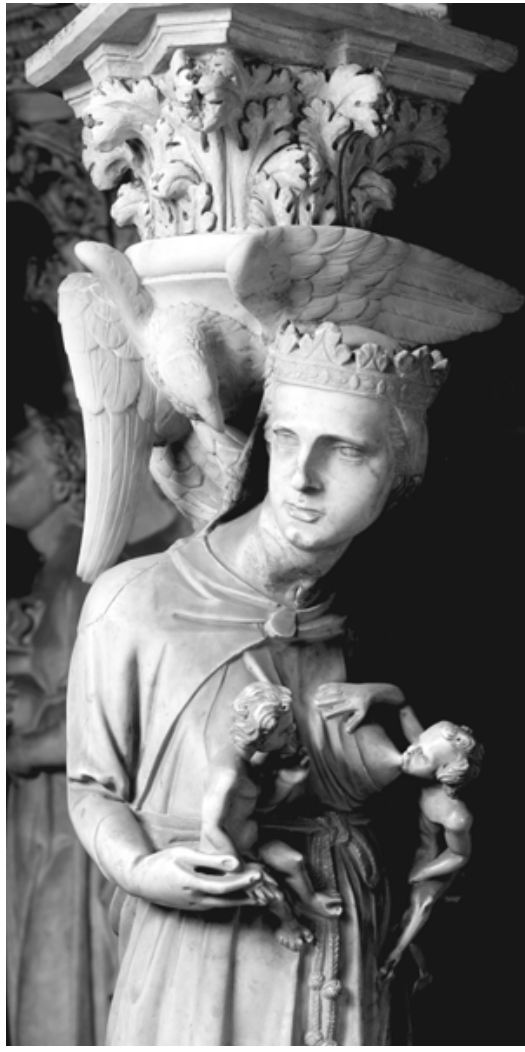

Figure 6.7: Giovanni Pisano, Charity or Ecclesia, 1310, Detail, Pisa, Cathedral

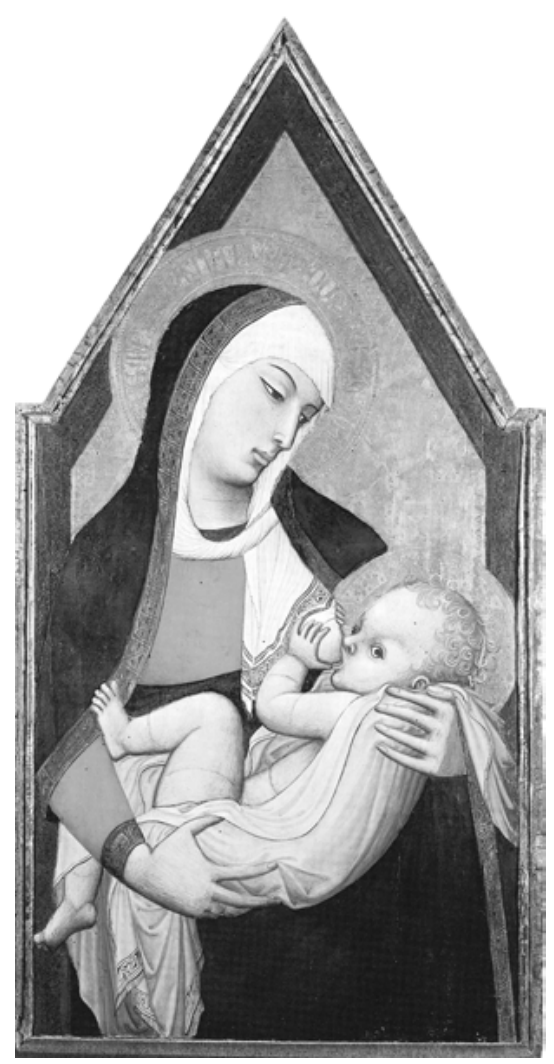

Figure 6.8: Ambrogio Lorenzetti, Madonna Lactans, ca. 1335

called Ecclesia on occasion, as a woman who through the slits of her garment nurses a child from each breast in 1310 (Figure 6.7). Tino da Camaino followed suit with a formally very similar representation in $1321 .^{41}$ In ca. 1330 , Giovanni di Balduccio sculpted Charity as a woman who breastfeeds two children from her left breast, ${ }^{42}$ and Ambrogio Lorenzetti painted one of the very first nursing Madonnas (Figure 6.8).43 While Seidel calls these Charity figures "maternal," it is important to point to their allegorical, universalizing function. Already in 1196, Wilhelm von Newburgh sees the nursing Madonna as yet another embodiment of Charity, who through her two nurslings nourishes all of suffering mankind. ${ }^{44}$ Thomas of Aquinas (1225-74) states unambiguously that the only and ultimate object of charity ought to be God. ${ }^{45}$ The semantic range of meanings associated with lactation imagery could not be wider, nor could the metonymic shifts produced by it be more ambitious. The proliferation of lactation imagery attests to Charity's importance as a "trope of tropes" à la Joel 
Fineman, i.e., as a figure of speech - here: visual allegory - that reflects on its own status as allegory and formally re-enacts the fertility it signifies. ${ }^{46}$

The Madonna Lactans also relates to representations of Christ Crucified, who through his blood promises redemption to all believers. Mechthild von Magdeburg (1212-94) writes in her revelations: "His wounds and her breasts were opened. The miracles poured, and the breasts flowed ... The blood came from mercy, like the milk, which I drank from my virginal mother."47 Such symmetrical views of Christ's blood and Mary's milk entered the visual arts in the early fifteenth century - among others, in a painting entitled The Intercession of Christ and the Virgin (ca. 1402) attributed to Lorenzo Monaco. ${ }^{8}$

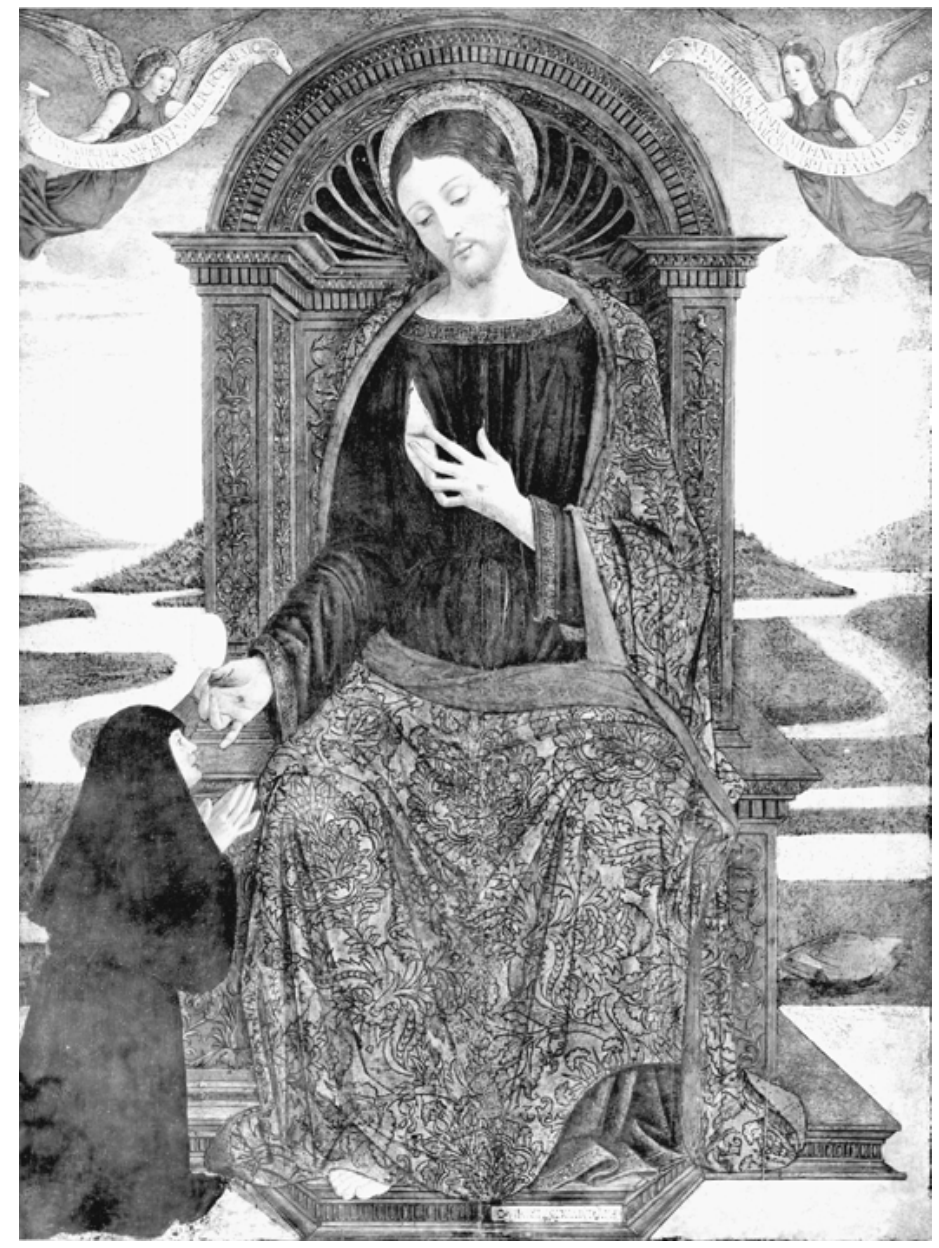

Figure 6.9: Quirizio di Giovanni da Murano, Christ about to Nurse a Poor Clare from his Wound, 1460-80 
Quirizio di Giovanni da Murano even depicts Christ offering his wound like a nipple in the V-hold typical of breastfeeding women to a Clarissan nun (146078) (Figure 6.9). Already in the twelfth century, William of Saint-Thierry (ca. 1075-1148) called Christ's spiritual nourishment "milk" in a commentary on the Song of Songs that drew on Saint Paul's letters: "I had to feed you with milk, not with solid food, because you weren't ready for anything stronger" (1 Corinthians 3:2).49

Because of Paul's equation of milk with Christian teachings, lactation metaphors survived even in seventeenth-century Protestant catechisms..$^{50}$ At the same time, milk-relics continued to enjoy great currency in Catholic regions. In 1618, Cardinal Tiepolo of Venice published a treatise on the miraculous rediscovery of a medieval milk-relic during reconstruction works at Saint Mark's Chapel. In this book, he explains in great detail how the Virgin's milk was so abundant that it sprayed onto a rock while she was resting during her flight to Egypt, and how it hardened to form a chalk-like substance, which, if powdered and dissolved in water, cured diseases and prolonged the milk-flow in mothers and nurses..$^{5^{1}}$ This is exactly the kind of discourse Erasmus of Rotterdam had made fun of a century earlier. In his colloquium "A Pilgrimage for Religion's Sake" (1526), he has the Virgin Mary herself complain - to Ulrich Zwingli, of all persons! - about being hopelessly overworked: "Every Thing was asked of me, as if my Son was always a Child, because he is painted so, and at my Breast, and therefore they take it for granted I have him still at my Beck, and that he dares not deny me any Thing I ask of him." ${ }^{2}$ She also regrets that she is no longer represented as Queen of Heaven but as a breastfeeding mom in raggedy clothes. Erasmus's two interlocutors ridicule contemporary Catholics' belief in milk-relics and poke fun at Saint Bernard, who, "when he was very old, had the Happiness to taste Milk from that same Nipple which the Child Jesus sucked." 53

In medieval Catholicism, milk, blood, and the body of Christ were interchangeable substances to be ingested. Caroline W. Bynum has shown how female mystics of the Middle Ages played with food-related metaphors to express their yearning for a union with Christ, a God they hungrily devoured..$^{54}$ In their writings and religious practices, they expanded Eucharistic forms of devotion to include self-starvation and the miraculous feeding of others. Sometimes, their bodies leaked nourishing matter. Thomas of Cantimpré (1201-72) remarks in his "Life" of Christina the Astonishing (1150-1224) that Christ filled her breasts with milk so that she could nourish herself.55 On another occasion, she produced miraculous oil in her breasts, with which she cured skin sores and other diseases. Lutgard of Aywières (1182-1246), another female mystic featured by Thomas, exuded healing oil from her fingertips after repeated visions of suckling milk from Christ's wounds. ${ }^{56}$ Gertrud von Oosten (d. 1358) experienced engorgement after meditating on the nativity, and Lidwina of Schiedam (d. 1433) had a vision of the nursing Madonna surrounded 
by lactating virgins. She was in the habit of breastfeeding a former caretaker, who in turn saw Lidwina's breasts fill with milk on Christmas day. ${ }^{57}$

Italian holy women were less apt at producing miraculous milk and other body fluids than their Flemish counterparts; they saw themselves as recipients of divine nourishment instead. Saint Catherine of Siena (1347-80), for example, was nursed repeatedly by both Christ and the Virgin Mary. ${ }^{8}$ Once, this miracle happened after she sucked off pus from the cancerous breast of a fellow mantellata [third-order nun].59 Monks and male mystics such as Saint Bernard of Clairvaux (1090-1153) also enjoyed the Virgin's milk in their visions, and they adopted maternal metaphors for themselves in legitimizing their authority as abbots. ${ }^{60}$ Saint Clare of Assisi (1194-1253) had visions of nursing from the breasts of Saint Francis, as reported by fellow nuns during her canonization proceedings in $1253 \cdot{ }^{61}$ In an illumination analyzed by Helga Kraft, a nun nurses from the breasts of the Virgin Mary. ${ }^{62}$

Both the Madonna Lactans and the representation of Charity in the visual arts developed within a gender-bending religious context that placed high value on the symbolic aspects of breastfeeding. The seemingly infinite supply of breast milk and the bliss it conferred on suckling infants appeared to fit form and content of the Christian message since the writings of Saints Paul and Augustine. If the lactation miracles mentioned above can be taken as an indication of how paintings of Caritas and the nursing Virgin resonated among viewers, it is reasonable to assume that Catholic beholders identified with both nurse and nursling. After all, giving and receiving - or, better, giving as receiving - went hand in hand in medieval definitions of charity as the highest religious virtue. ${ }^{63}$ In paintings such as Lorenzo Monaco's and Quirizio da Murano's, in which donors direct their hopes for intercession to both Christ's wound and Mary's breasts, the ancient theme of divine adoption and protection re-emerges, as the veneration of Mary's milk and Christ's chest wound is seen as conferring and constituting spiritual kinship.

Art historians and religious scholars are still debating whether the nursing Virgin had the didactic function of exhorting mothers to breastfeed their infants. Were contemporary women expected to imitate the Madonna, and if so, how? Margaret R. Miles, in her epoch-making article "The Virgin's One Bare Breast," denies the status of the Madonna Lactans as a maternal role model, suggesting that Mary's breastfeeding of her son marked her uniqueness in a culture in which wet-nursing was commonplace. ${ }^{64}$ Aelred of Rievaulx (1110-67) was of the opinion that "she [Mary] is our mother much more than our mother according to the flesh," ${ }^{5}$ a view that the many lactation miracles of male and female mystics who received the grace of Mary's milk seem to confirm. Direct competition with the Madonna Lactans as a dispenser of spiritual nourishment was rare, confined to Flanders, and possibly blasphemous. Saint Bernardino of Siena, for example, saw Mary's importance in redemption history as rivaling 
Christ's. ${ }^{66}$ Clarissa W. Atkinson and Rosemary Drage Hale expand on Miles's view by arguing that both women and men identified with the Virgin Mary insofar as she was a role model for spiritual, not corporeal or biological, motherhood. ${ }^{67}$ Naomi Yavneh and Charlene Villaseñor Black, by contrast, view the Madonna Lactans in the context of fifteenth-century Florentine "pro-maternal lactation propaganda" and sixteenth-century humanist polemics against wet-nursing, but they lack records from contemporary mothers to prove their point. ${ }^{68}$

Megan Holmes shifts the debate by investigating the intelligibility of the nursing Madonna's religious meaning in the late fifteenth and early sixteenth centuries, when naturalism in the arts demanded an anatomically correct portrayal of the Virgin's breast. In earlier paintings, Mary's breast was shown as slightly deformed and dislocated in order to highlight its symbolic significance, but Renaissance representations threatened to blur the distinction between the Madonna's spiritual role and her formal resemblance to human mothers. ${ }^{6}$ As a result, Mary's breasts became eroticized to the point at which their spiritual meaning was hard to communicate. The extent to which more naturalistic fifteenth-century Flemish representations of the Madonna Lactans - for example, by Rogier van der Weyden - contributed to the abandonment of the dislodged breast in Italian art still remains to be investigated.

The spiritual motherhood of Elena Duglioli (1472-1520), a spontaneously lactating saint, offers a late, and most spectacular, example of forms of devotion that according to her hagiographers were inspired by identification with the Virgin Mary..$^{\circ}$ Her extravagant religious practices represent the last flourishing of a religious culture that saw the Madonna's nursing of Christ as a symbol of divine protection. In the Italian context, Elena is unique in her resemblance to Mary; up until then, only Flemish mystics Lidwina of Schiedam and Gertrud van Oosten had experienced virginal engorgement after meditating on the nursing Madonna. Elena became known for the anti-libidinal qualities her milk could transmit, in direct defiance of the contemporary scientific discovery of the breast as an erogenous organ..$^{11}$

As Gianna Pomata informs us, Blessed Elena, who for many years lived with her husband Benedetto Dall'Olio in a chaste marriage, found her breasts to be filled with milk one day in 1510. She took this to be a sign of God's grace, especially since she resumed menstruating at the same time. As already mentioned, virginal lactations were within the law of nature if they were accompanied by amenorrhea, according to medical theories of the time. Elena would have liked to use her milk to nurse foundlings, but God forbade it to her in a vision. Instead, she helped raise the baby of her niece. She soon moved on to breastfeed grown men, however, presenting herself as their spiritual mother, as if re-enacting an ancient rite of spiritual adoption. Among her spiritual sons were her confessor Pietro Ritta and Antonio Pucci, papal nuncio, Bishop of 
Pistoia in 1519 and Cardinal in 1531. According to Pomata, Pucci came to her with the express wish to be rid of his carnal desires:

"[He] wished to have the milk "directly from the maternal breast," longing for "the singular grace ... of turning into a baby again [come fanciullo rimbambire], and from a woman obtaining the first act of infant feeding ... So that the elect of God on his knees received the heavenly liquor with plenty of tears, devotion and reverence, as if suckled at the divine breast of the glorious Mother of God herself"."72

It is ironic that among the six anatomists asked to assist in Elena Duglioli's post mortem dissection, initiated by clerics who wanted to find material proof of the miraculous nature of her milk, was Berengario da Carpi, who discovered the erogenous function of both male and female nipples. ${ }^{73}$ Just as contemporary erotic representations of the breast in visual culture clashed with the spiritual values of Catholicism, the anti-erotic nature of Elena's spiritual nursing sessions became doubtful from the point of view of early modern

Figure 6.10: Jacopo della Quercia, Charity, 1409-19, Original Replaced by Tito Sarrocchi in 1868, Siena, Fonte Gaia

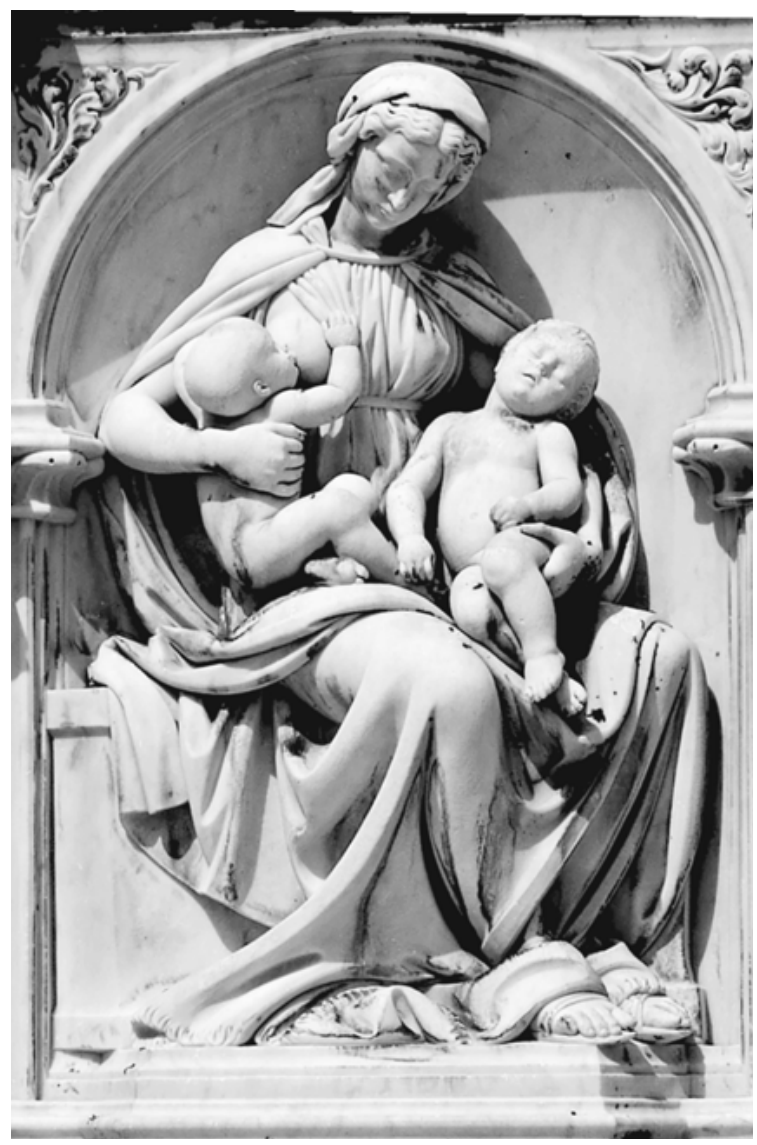




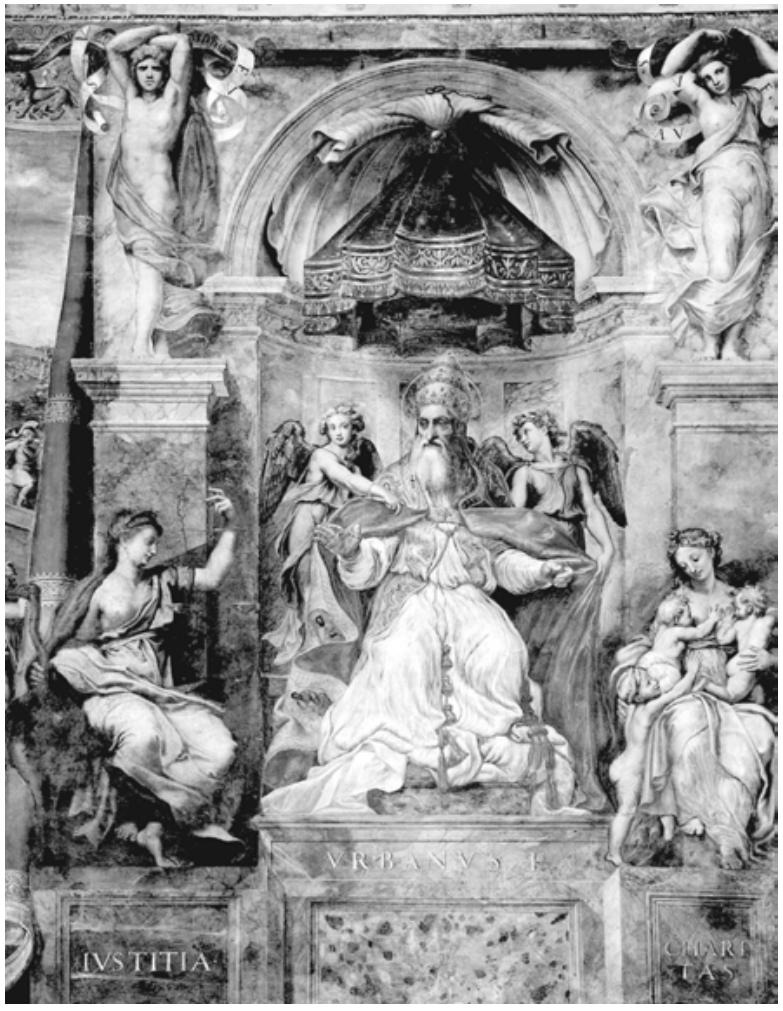

Figure 6.11:

Giulio Romano or Raphael, Charity, 1520-24

science. Unsurprisingly, her two autopsies did not reveal any unambiguous signs of the supernatural origin of her milk, much to the disappointment of her hagiographers, who complained that "the medical men ... are always enemies of miracles and have recourse to the works of nature."74

By the time of Elena's death in 1520, lactation imagery had become quite varied, to include the representation of wet-nurses and mythological hybrid creatures as well as the first renderings of parental breastfeeding à la Maximus. Even though the quintessential erotic breast was small and dry, lactation scenes could be quite sensual. ${ }^{75}$ Charity's bosom, for example, had in the course of the fifteenth century become more naturalistic, free of the stylistic alienation to which the nursing Madonna's "one bare breast" was subjected..$^{6}$ Jacopo della Quercia's sculpture at the Fonte Gaia in Siena (1409-19) shows her seated, with one big round breast exposed, suckling an infant (Figure 6.10). Another baby rests asleep on her lap. Andrea Guardi depicts her surrounded by three small children, shoulders exposed, in his choir relief of Santa Maria della Spina in Pisa (1452). ${ }^{77}$ Filippino Lippi's Charity (1487-1502) is standing upright in classicizing elegance, shoulders and breasts revealed. One baby is sitting on her right arm, another one is suckling from her left breast, and a third one clutches her 
right leg. ${ }^{78}$ Giulio Romano's Charity, sometimes attributed to Raphael, is even more sensual, with one baby nursing, another one playing with her breasts, and a toddler reaching up to touch her (Figure 6.11). This fresco was completed four years after Elena died (1524). Starting in the 1490s, the Madonna Lactans, likewise, became quite erotic, revealing one or both of her beautiful breasts to the viewer. The new distancing devices included showing her as queen of heaven or enthroned on a marble dais to make up for the omission of a deliberate

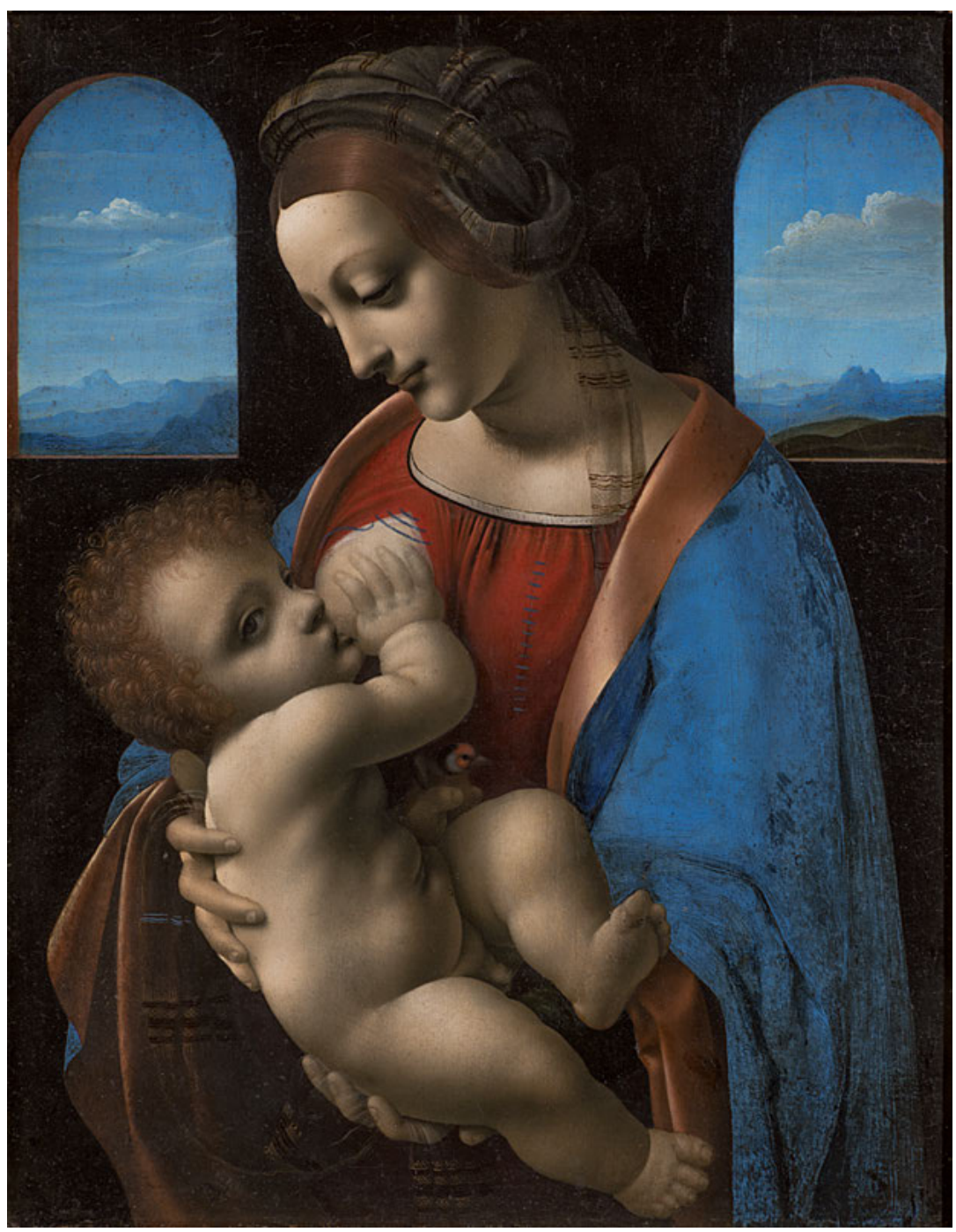

Figure 6.12: Leonardo da Vinci, Follower, Madonna Lactans, ca. 1490 


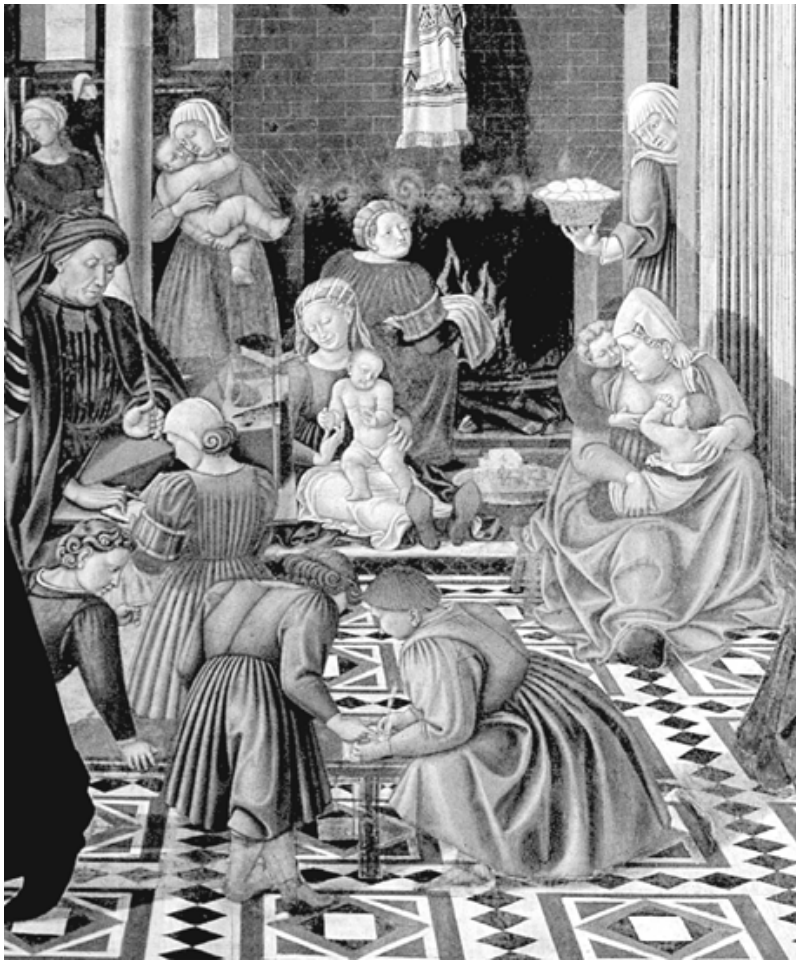

Figure 6.13:

Domenico di Bartolo, The Assignment and Payment of Wet-Nurses and the Marriage of Foundlings, 1443, Detail

dislocation of her breasts that contemporary viewers would no longer have tolerated.79 Only Leonardo da Vinci - or one of his followers - portrayed her in a highly intimate scene, with baby Christ searching for her nipple, her gorgeous breast exposed through a slit in her garment (ca. 1490) (Figure 6.12). ${ }^{80}$

Less eroticized were the representations of wet-nurses and "passive" Charities, i.e., women beggars with nursing infants and small children in their care. Domenico di Bartolo (1400/04-1445/47) painted both varieties in his frescoes in the Sala del Pellgrinaio of the Ospedale di Santa Maria della Scala in Siena. In The Assignment and Payment of Wet-nurses (1443), three wet-nurses perform their tasks in the interior of the foundlings' ward where a swaddled newborn is handed over to a veiled assistant (Figure 6.13). The nurse in the back stands upright, cuddling a naked infant; a second one is seated, playing with a baby in her lap; and a third one nurses a baby, Charity-like, with another infant clinging to her back. In The Distribution of Alms (1443), a woman carries a naked infant who is reaching for her breast, and she holds a toddler at her left hand, who waits patiently for her turn (Figure 6.14). Next to her, a poor man receives new clothes and a lame beggar crouches on the floor. Another womanand-child-couple lines up in the background for their bread ration. These frescoes are exceptional for their "reality-effect," i.e., the amount of interior 
Figure 6.14:

Domenico di Bartolo,

The Distribution of

Alms, 1443, Detail

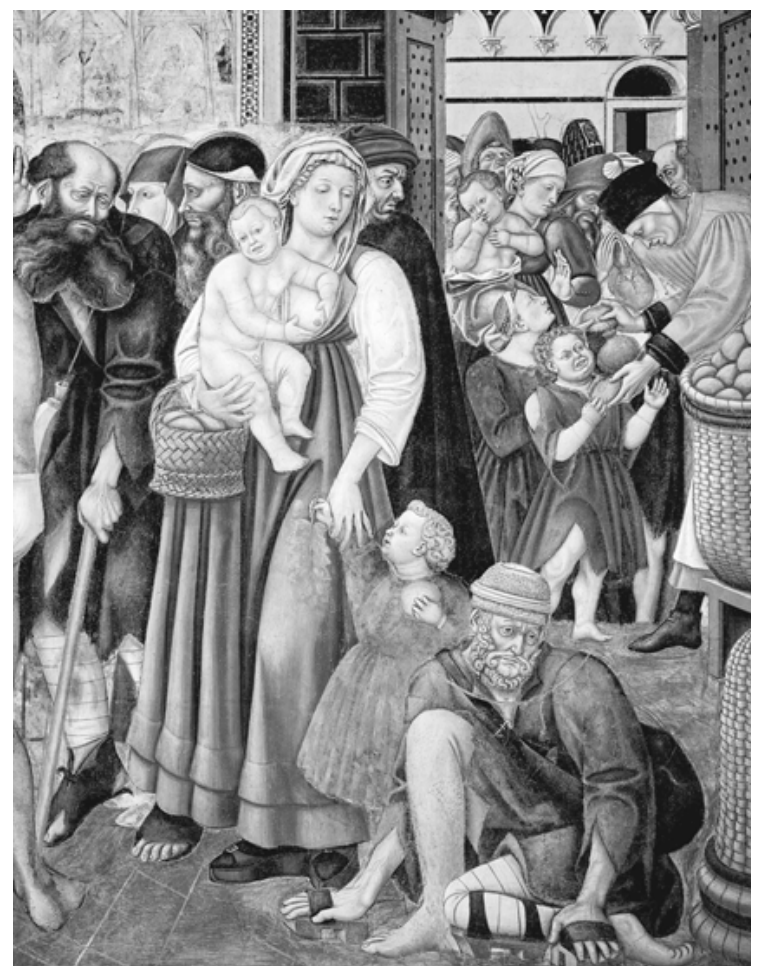

detail depicted, the lively composition of their many varied figures, and the naturalistic representation of both alms-seekers and officials working for the hospital. The women-and-child dyads and triads are particularly noteworthy for the care Bartolo took in depicting them in a range of different narrative poses and configurations. ${ }^{81}$ Neither the nurses nor the female beggars are particularly eroticized, probably in order to highlight their working-class status.

Another wet-nurse shown in the act of suckling a baby is featured in Ghirlandaio's fresco The Birth of Saint John the Baptist (1487-88) in Santa Maria Novella, Florence (Figure 5.4). In this rather solemn and stern composition, two wet-nurses vie for the same holy child, while Saint Elizabeth, poised and disciplined, sits on a throne-like bed, accepting red wine and receiving a stream of female visitors. ${ }^{82}$ A classicizing "dovizia," carrying a fruit basket and another flask of wine, approaches from the right. ${ }^{83}$ The fresco is unique for its depiction of a suckling baby - in all other confinement room scenes except for Tintoretto's sixteenth-century versions, baby Mary and baby John are being washed and swaddled, never nursed. ${ }^{8}$ Art historians have pointed to the realistic interior settings of these, quite popular, representations of delivery rooms, but the absence of nursing scenes in the iconographic tradition indicates a formal indictment that may have derived from the apocryphal sources on which they 


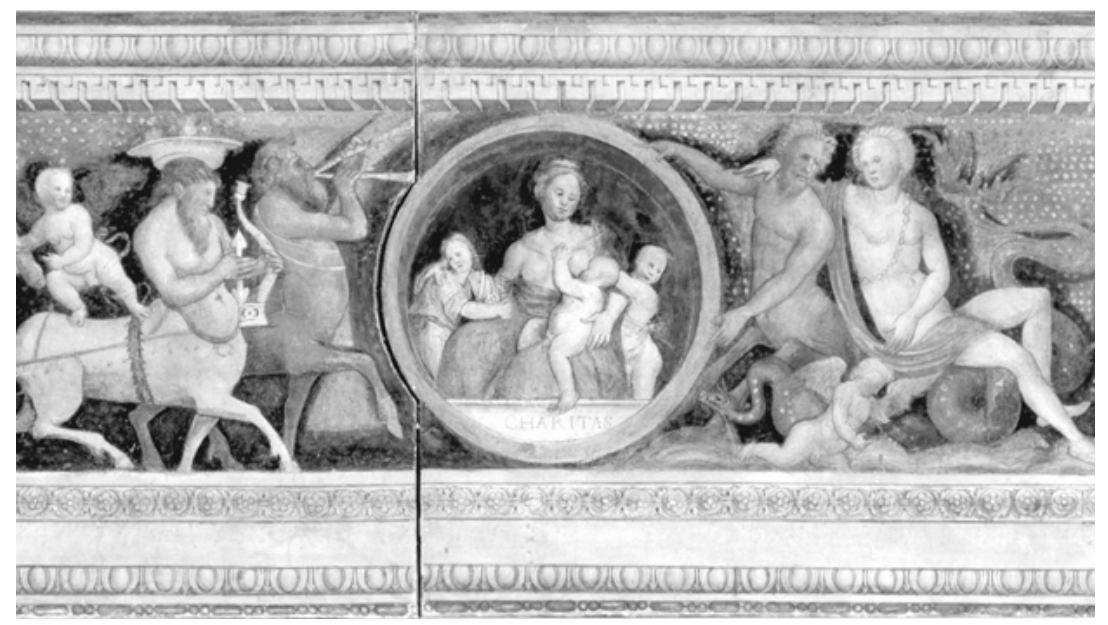

Figure 6.15: Marcello Fogolino, Charity, 1516-25, Predella, Detail

are based. In texts such as the Book of James (ca. $145 \mathrm{CE}$ ), which, among others, inspired Jacopo di Voragine's Golden Legend (ca. 1260), lots of birth assistants populate holy birthing scenes, but wet-nursing is never explicitly mentioned..$^{85}$ The violation of this prohibition in Ghirlandaio's fresco is thus all the more remarkable, since it depicts not only a non-maternal but also promiscuous nursing of baby John, who is cared for by two wet-nurses simultaneously.

Among the more eroticized lactation scenes that entered early sixteenth-century visual culture were depictions of mythological hybrid creatures. Marcello Fogolino's frieze painted for the Villa Trissino-Muttoni (1516-25) is of note, as it combines the depiction of virtues - among them, a breastfeeding Charitas with a procession of sea nymphs, centaurs, and Eros figures (Figure 6.15). The tondo featuring Charity is being held by a male sea creature, on whose curvy fishtail a naked Nereid lounges. Charity is bare-breasted and surrounded by three children. Next to the mermaid couple a dragon opens its muzzle. He faces a winged sphinx, who breastfeeds a mermaid baby and holds up a tiny dragon in her right hand. According to Gunter Schweikhart, an ancient sarcophagus inspired the mythological portions of this frieze. ${ }^{86}$ Why Fogolino combined the portrayal of Christian and humanistic virtues with the depiction of ancient hybrid sea creatures and centaurs, mirroring Charity with a breastfeeding sphinx, remains a mystery, but the effect of Charity being showcased by a longtailed merman is decidedly ironic. Also noteworthy is Fogolino's depiction of Pietas, consisting of an oversized woman offering a bread roll to an old bearded man whose head reaches up to her bosom (Figure 6.16). An uncanny resemblance to Pero and Cimon emerges, even if the two do not share any milk. All virtues other than Charity are depicted in formal analogy to Pietas. 


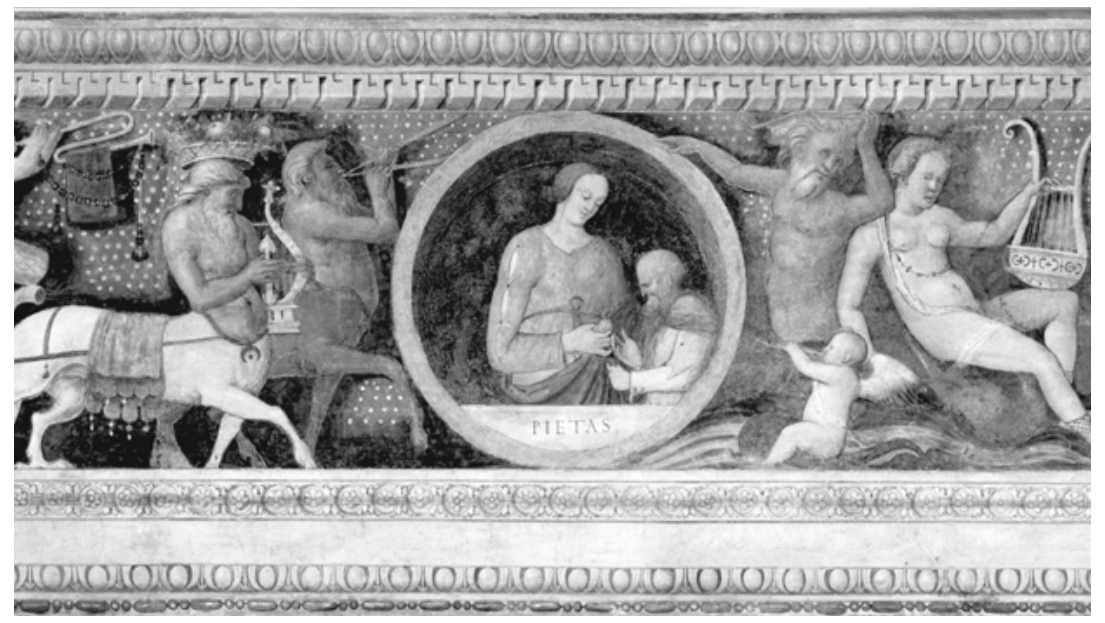

Figure 6.16: Marcello Fogolino, Pietas, 1516-25, Predella, Detail

A similar conflation of mermaids and Charity appears in a painting attributed to Giulio Romano and his workshop, completed during his Mantovan period $(1527-45){ }^{87}$ It shows a lovely mermaid with five breasts, arranged in a semi-circle on her chest, from which seven mermaid children of varying ages suckle eagerly (Figure 1.43). The group seems to be protected by a giant shell in the back; the mermaid babies' snake-like, curvy tails are hopelessly intertwined. Maybe this whimsical and thoroughly eroticized Charity was inspired by Giovanni Maria Falconetto's polymast statue from his Archaeological Landscape, a fresco adorning the Sala dello Zodiaco in the Palazzo d'Arco in Mantua (before 1535) ${ }^{88}$ This dreamlike, fantastical figure sprouts eleven breasts from which milk drips onto tiny naked children. As enigmatic allegory, which probably embodies Nature and Abundance, she opens both arms in a gesture of welcome and generosity. ${ }^{89}$

Also around 1520, Venetian painters developed what I like to call the iconography of the "breastfeeding woman in a corner," i.e., representations of Charity-like figures that function as decorative details, allegories, and narrative elements of the biblical plots they embellish. ${ }^{\circ}$ They are usually placed in one of the paintings' bottom corners, thus foreshortened and highly visible, dominating the picture plane. At the same time, they are marginalized figures, crouching at the edges of the composition, not directly participating in the events they witness. The first example of this mixed use of Charity half allegory, half narrative bystander - is Titian's woodcut variously entitled Moses Divides the Water or The Drowning of the Pharaoh's Host in the Red Sea $(1515-17)$ (Figure 6.17). ${ }^{91}$ In the lower right corner of this woodcut, and next to Moses commanding the waters, sits a woman who nurses her child, one breast 


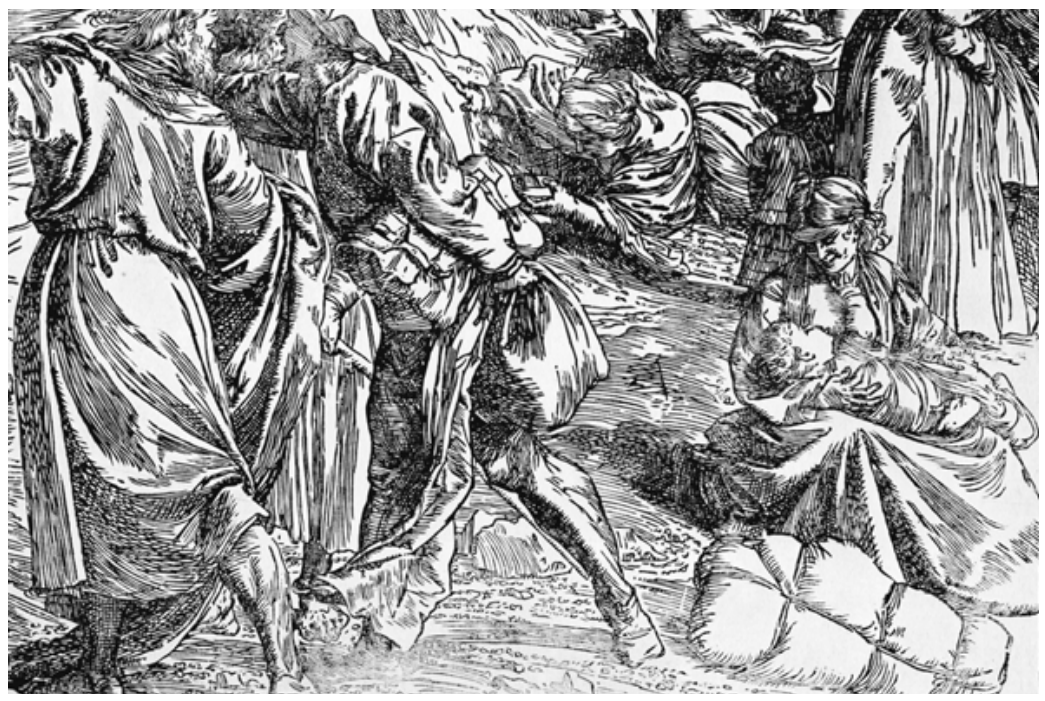

Figure 6.17: Titian, Moses Divides the Water, 1515-17, Detail

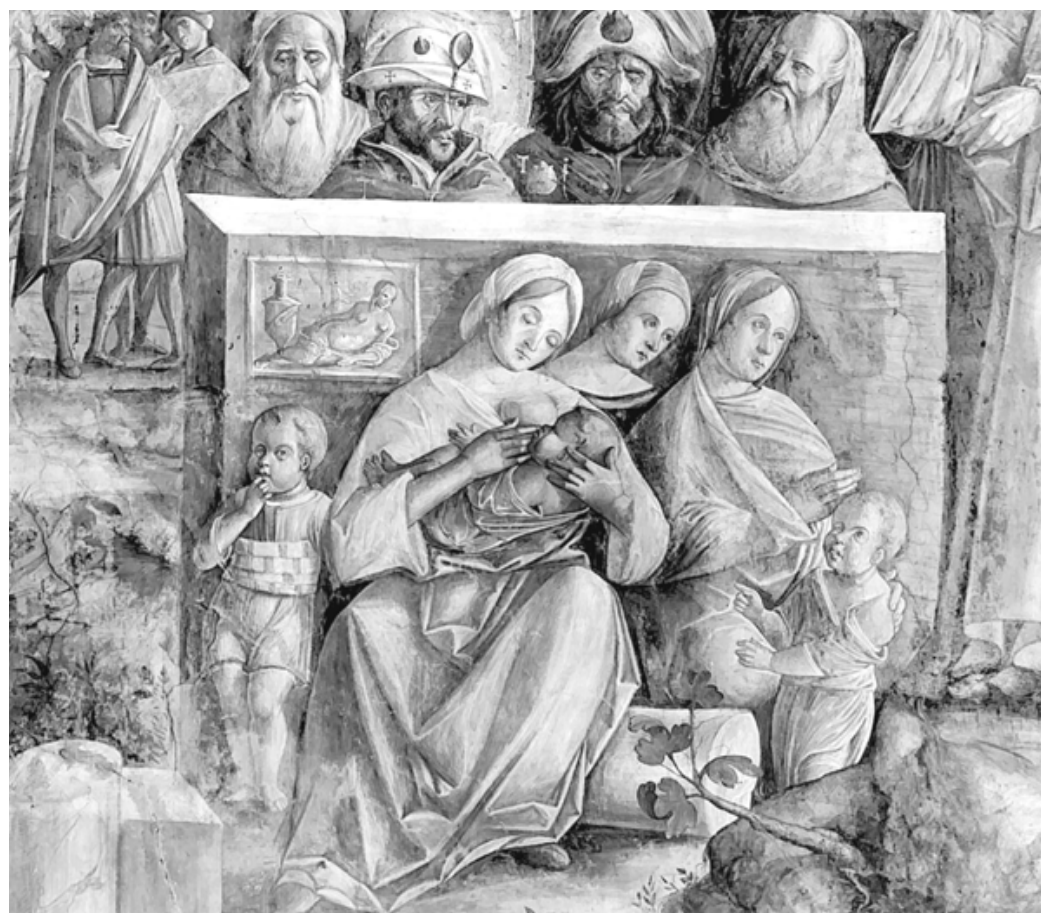

Figure 6.18: Giovanni Antonio Coróna, The Preaching of Saint Anthony, 1509, Detail 
exposed. Facing the beholder, she seems oblivious to the momentous events Moses unleashes. Entirely absorbed in her task, she smiles at the nursling who caresses her cheek. At the same time, she is part of the Israelites' flight and rescue, foreshadowing and anticipating their promise of peace and prosperity.

A similar, narrative use of Charity is evidenced in Giovanni Antonio Coróna's fresco of The Preaching of Saint Anthony in the Scuola del Santo in

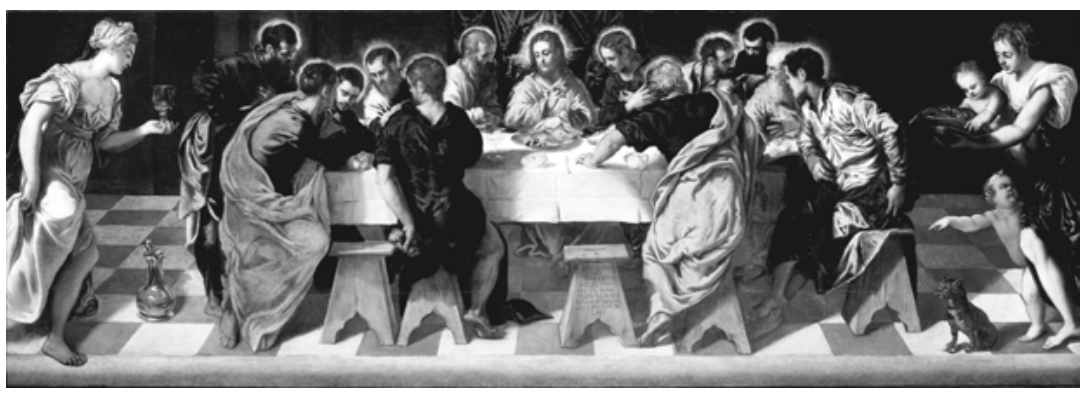

Figure 6.19: Tintoretto, Last Supper, 1547

Padua (Figure 6.18)..$^{92}$ Here a group of three women and their children faces the viewer in the lower right corner of the fresco, divided from the preacher's male audience by an ancient ruin. They lean against this architectural element, presumably a wall of a former Roman villa, which in its upper left corner is embellished with a relief of a reclining Venus and a tall vase. The woman right underneath the relief nurses her baby, eyes downcast. A toddler snuggles up to her right arm and shoulder, directly addressing the viewer. The women are protagonists of the scene, listening intently to Saint Anthony's sermon, but they also function as symbols by embodying the dawn of a new era, replacing the erotic consumption of Venus's breasts with the spiritual practice of charity.

A generation later, this mixed use of Charity figures - passive and active, allegorical and narrative - would become the hallmark of Tintoretto's religious paintings, starting with his Last Supper in San Marcuola (1547) (Figure 6.19), The Miracle of Saint Mark Freeing the Slave (1548),93 The Miracle of the Loaves and Fishes (1545-50), 94 and The Presentation of the Virgin (1552) (Figure 6.20), culminating in his decorative program for the Scuola Grande di San Rocco (1575-87).95 Tintoretto's representations of women engaged in reproductive activities - including begging, the serving of food, and nursing - are complex. In The Presentation of the Virgin, nursing Charities, probably inspired by the begging woman-with-child couple in Titian's painting of the same title (1534-38), are decoratively placed on the temple's intricately embellished staircase, dwarfing the three-year-old Virgin Mary in the back. In his Last Supper of San Marcuola, two serving women approach the apostles, one carrying a 


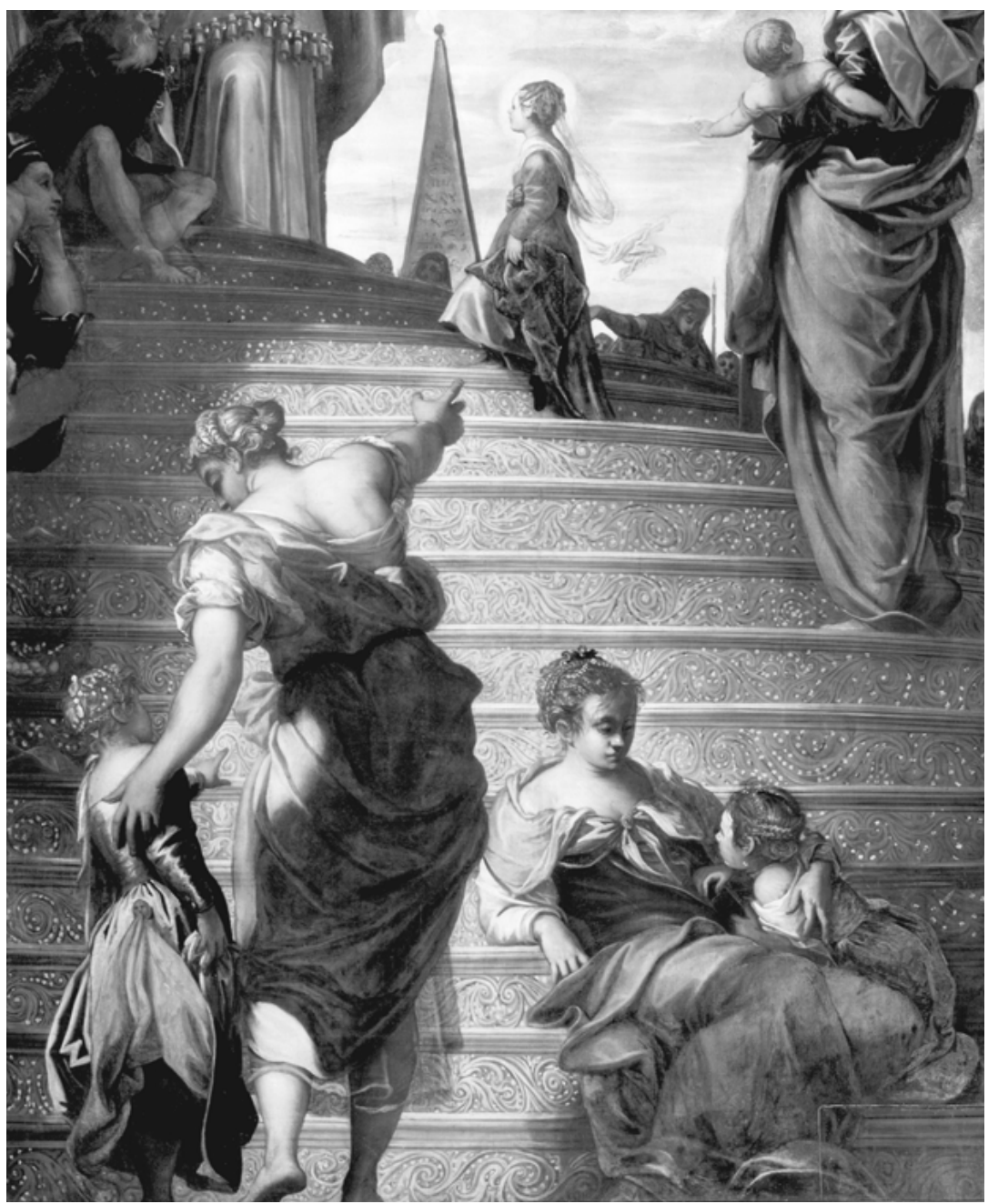

Figure 6.20: Tintoretto, The Presentation of the Virgin, 1552, Detail

chalice with wine, the other one bringing a platter with bread. This latter servant also carries a naked infant on her arm, Charity-like, and is accompanied by a toddler to her right. Also in The Miracle of Saint Mark Freeing the Slave and in The Miracle of the Loaves and Fishes, women with small children in their care accompany the protagonists. In all these instances, the women are reminiscent of passive Charity figures, i.e., women with small children in their care asking for alms, but they also embody the active values of Charity. Dispensing the spiritual nourishment of milk, they anticipate the Virgin's nursing of Christ and accompany Jesus in his offering of bread and wine. 
Tintoretto is, to my knowledge, unique in incorporating Charities into his various renderings of the Last Supper, i.e., women engaged in the highly symbolic acts of serving bread and wine to the apostles or asking for scraps from Jesus's table. Charities often serve as visual points of entry into Tintoretto's religious paintings, promoting his view of charitable activities as the most important value of Catholicism, embodying and anticipating Christ's promise of redemption. They also connect the Old Testament with the Gospels visually and semantically, as in the Scuola Grande di San Rocco. In his Circumcision of Christ (1587), a breastfeeding mother waits patiently for her turn, watching as baby Christ is being circumcised (Figure 6.4); in Moses Striking the Rock (1577), a nursing woman mirrors and doubles Moses's miracle of spouting life-giving fluids; $9^{6}$ and in The Baptism of Christ (1578), the suckling mother's illuminated breast competes with Christ's shoulder, foreshadowing his sacrifice and promise of redemption to come. ${ }^{97}$

Charity became a highly embattled concept ever since German Protestants started doubting the redemptive value of charitable acts and questioned the theoretical value of allegorical representations in religious art and literature. But already long before the onset of the Reformation in 1517, Charity had crossed into the secular realm as a rather complex and multifaceted virtue. Adult nursing scenes that may have been inspired by Maximus's anecdotes blurred the boundaries between ancient Pietas and medieval Caritas. In 1150, for example, a manuscript preserved in the convent library of Engelberg was decorated with the image of a woman from whose naked breasts two old men

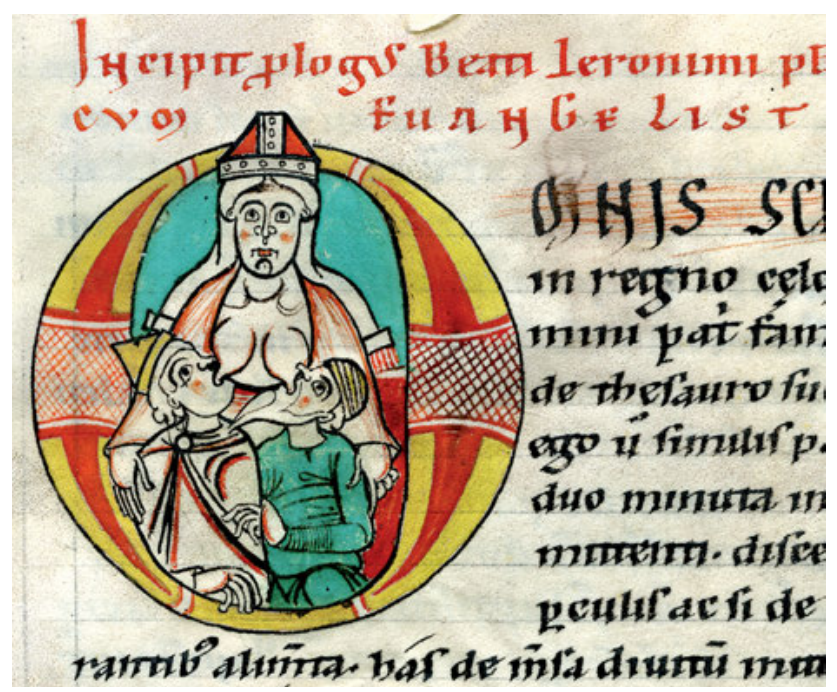

Figure 6.21: Woman Nurses Two Old Men from her Breasts, ca. 1150, Illumination, Detail 


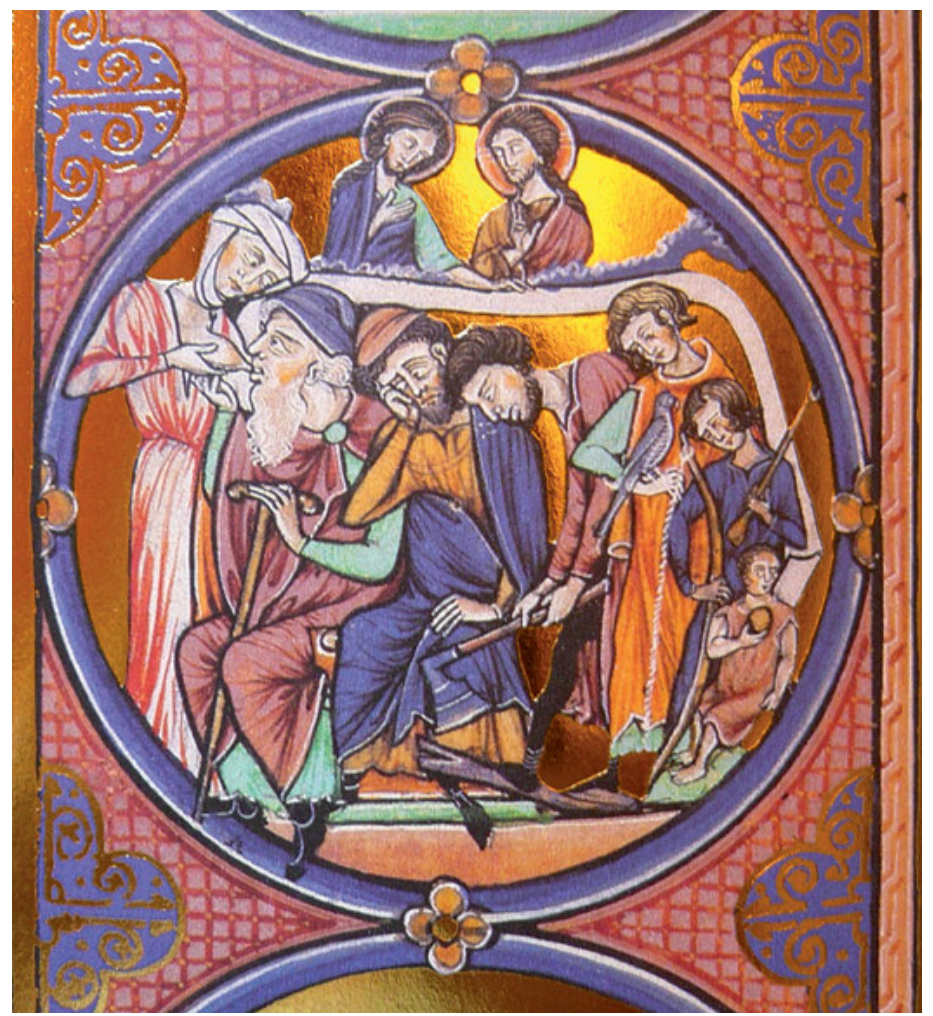

Figure 6.22: The Six Ages of Man, 13th c., Illumination, Detail

suckle milk (Figure 6.21). Wearing papal accoutrements such as mitre and stole, she surely represents Ecclesia nursing her believers..$^{8}$ A century later, in a "moralized Bible" from Toledo, an illumination of The Six Ages of Man shows a young woman nursing a seated, bearded old man (Figure 6.22). 99 And in 1491, a Flemish illumination of Boetius's On the Consolation of Philosophy shows Philosophy nursing her adult male devotees (Figure 6.23), possibly adapting Pisano's theme of Grammar Nursing her Pupils (1302-11) (Figure 6.24). ${ }^{100}$

In the fifteenth century, images of all-female lactation scenes started to appear, due to the popularity of Maximus's mother-daughter story and its adaptation by Boccaccio, as already mentioned (Chapter 4). Three French illuminations of Boccaccio's young Roman woman and her mother represent the very first renderings of all-female lactation scenes in the visual arts (Figures 1.5, 4.4 and 4.5). In 1473, the motif appears as a woodcut in a German print version of Boccaccio's Famous Women (Figure 4.6). ${ }^{101}$ In later centuries, Maximus's mother-daughter couple decreased in popularity, especially compared to the fortune Pero and Cimon started to enjoy. It re-appeared on an early 


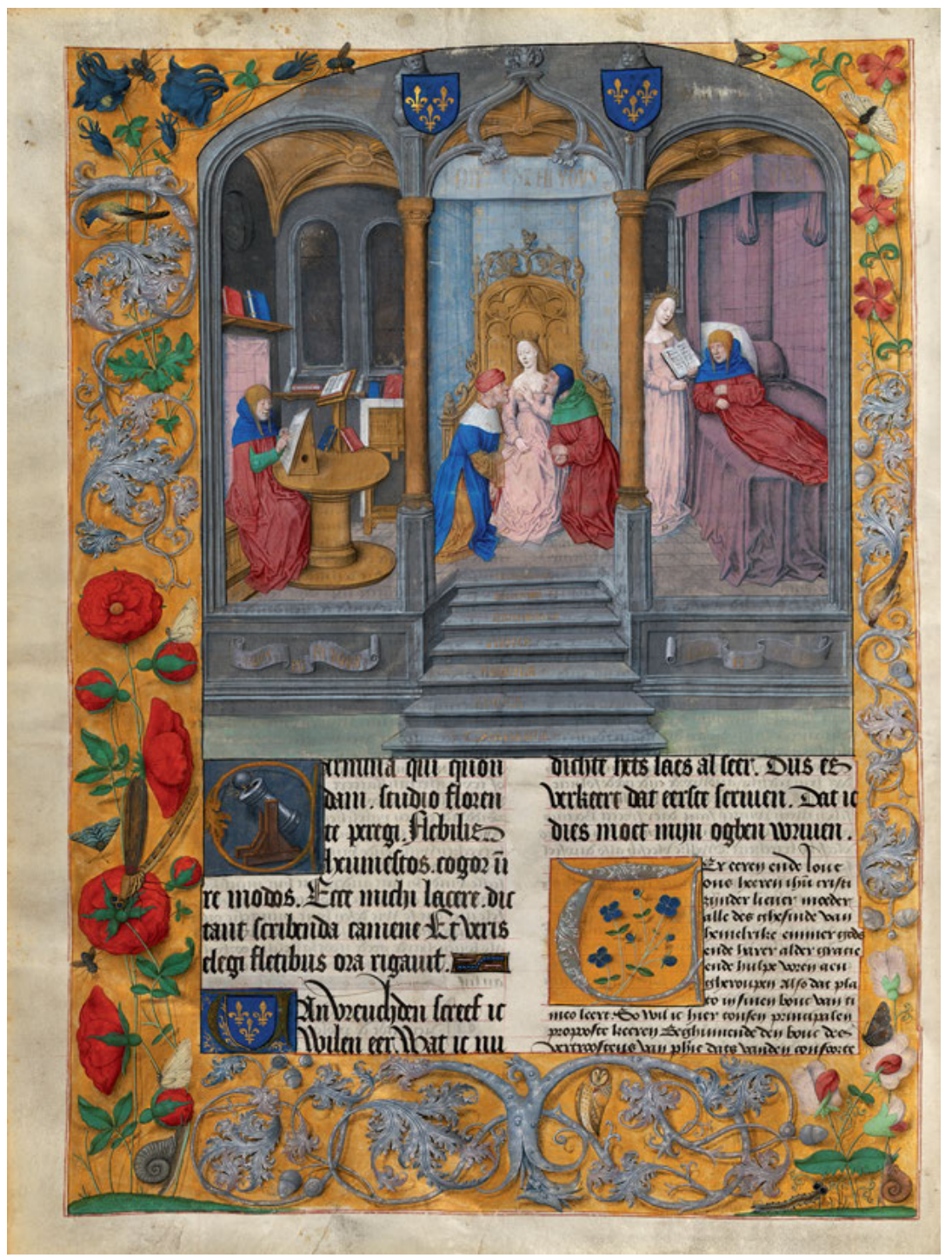

Figure 6.23: Philosophy, Sitting on a Throne, Nursing Boethius and another Philosopher from her Breasts, 1491, Illumination

sixteenth-century bronze plaque (Figure 1.7), a carved chessboard by Hans Kels the Elder (1537) (Figure 1.9), a French woodcut by Sébastien Nivelle (1572) (Figure 2.4), and a beautiful drawing by Guercino (1591-1666) (Figure 3.12), in addition to Poussin's The Gathering of the Manna (Figure 3.3). ${ }^{102}$ Andor Pigler even lists an oil painting by Gregorio Lazzarini (1655-1730), which, however, 


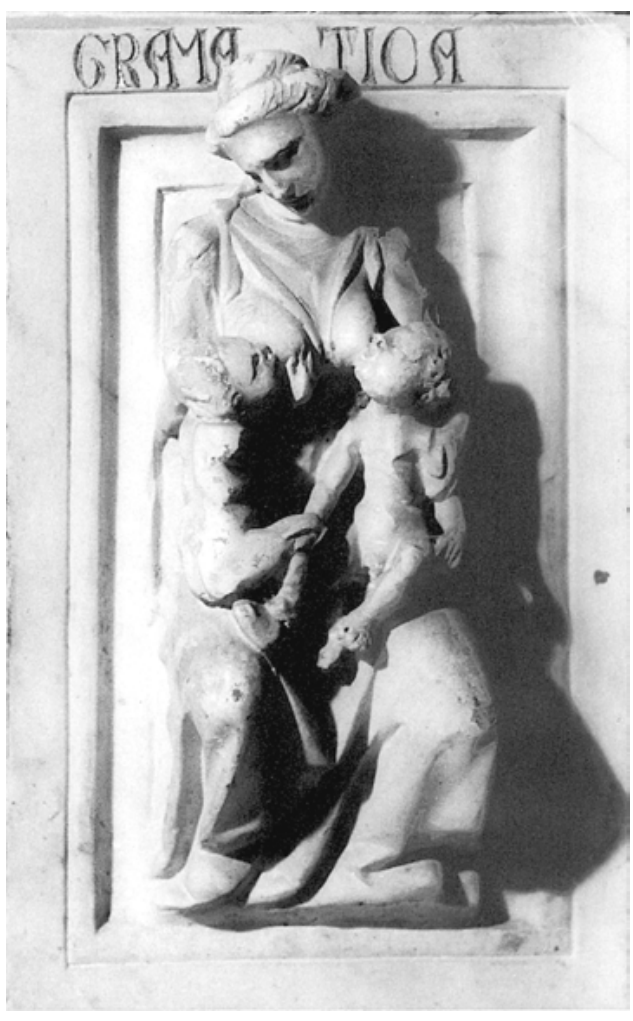

Figure 6.24: Giovanni

Pisano, Grammar, 1302-11,

Detail

is no longer extant. ${ }^{103}$ Three further Roman Charities of the mother-daughter variety appeared in the revolutionary period.

A further expansion - and possibly confusion - of Charity's meaning and associations came as a result of the success enjoyed by Maximus's story of Pero and Cimon since the later fifteenth century. Lactation imagery was, or would become, fairly complex by the time Elena Duglioli performed her spiritual nursing sessions. Adult breastfeeding scenes had entered visual culture, and Charity was eroticized to the point of becoming circumspect as a religious value. Scientific curiosity about the female body, in tandem with artists' desire for its anatomically "correct" visualization and classicizing eroticization, opened up a discursive space for the attribution of new significations to the lactating breast. Elena seized the opportunity to insert herself into a highly charged debate, by proposing to endow the practice of adult nursing with a spiritual meaning she may have derived from saints' legends, in open defiance of contemporary discoveries about the erogenous effects of stimulation of the nipple. She may, of course, also have been prompted by news about the use of wet-nurses by aging male clergy in Rome (see Chapter 4). Her death in 1520 concluded a long chapter in the history of medieval thinking, dreaming, and 
meditating upon the female breast as a signifier of religious desire, symbol of unmediated access to God's promise of redemption, and sign of another world to come. In the course of the sixteenth and seventeenth centuries, Charity and the Madonna Lactans continued to be painted on occasion but had to compete for meaning in a visual universe that now included queer lactation scenes such as Giulio Romano's Jupiter Suckled by the Goat Amalthea (before 1531) (Figure 6.25), Tintoretto's Creation of the Milky-Way (1575-80), ${ }^{104}$ and Ribera's Bearded Woman (1631) (Figure 5.2). Even Venus, quintessential object of desire, was occasionally shown as having breasts full of milk, as in Paolo Veronese's Venus and Mars United by Love (1570s) (Figure 5.3) and Rubens's Minerva Protects Pax from Mars (1630) (Figure 3.16). ${ }^{105}$ But most importantly, Charity and the Madonna Lactans had to stake out their territory vis-à-vis the burgeoning iconography of Pero and Cimon, which eventually came to eclipse the intelligibility of a religiously enhanced breastfeeding picture. Lactation imagery had become highly differentiated and complex since at least the sixteenth century, but a common characteristic of all those breastfeeding mythological creatures, wet-nurses, goddesses, and Charities is an emphasis on the non-exclusively maternal use of their milk and the eroticization of their lactating breasts. While the promiscuity of milk exchange seems to provide a counter-discourse to the "straight" and heavily policed line in which paternal blood was supposed to be passed down the generational ladder, the lactating virginal breast signified the utopian dimension of spiritual desire in Catholicism. In both contexts, lactation imagery appears as a heavily allegorized and "other" form of speech - or visual

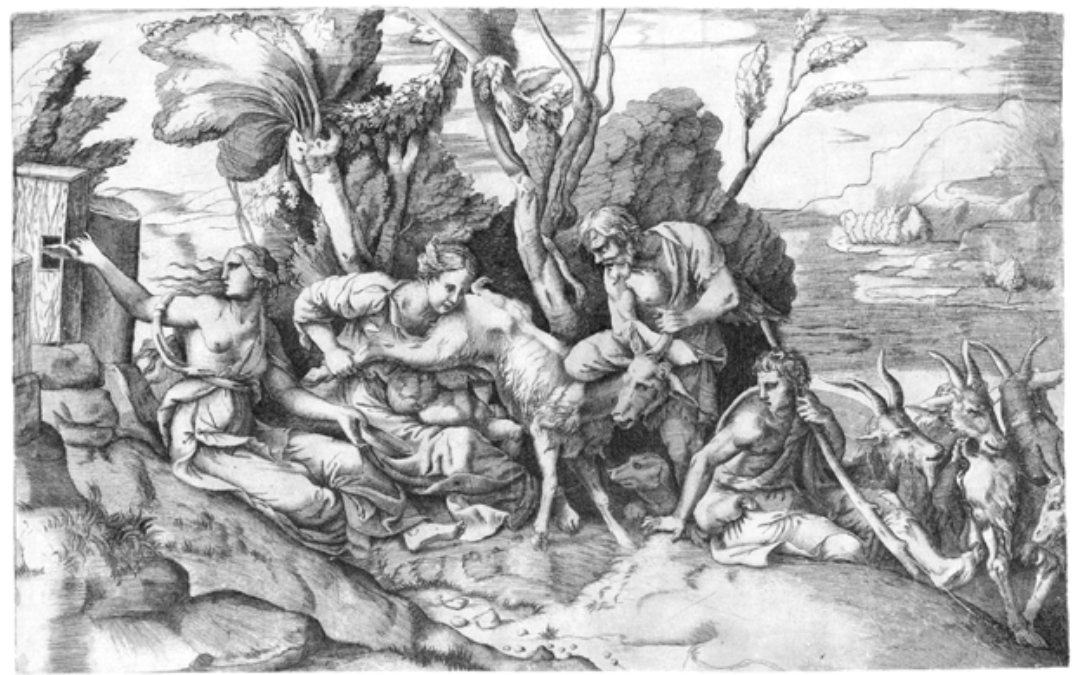

Figure 6.25: Giulio Bonasone, after Giulio Romano, Jupiter Suckled by the Goat Amalthea, after 1531 
rhetoric - that rivaled and threatened to subvert the normative legal discourse on family formation and the church's institutionalized practices of devotion. Pero and Cimon are important protagonists in this visual trend to configure the lactating breast as a queer, i.e. non-normative, signifier of desire.

In concluding, I would like to suggest how linking theories on allegory with Freud's language of the unconscious might open up new ways of thinking about the lactating breast in medieval and Renaissance art. Already in 1980, Joel Fineman proposed that figurative speech might indicate the allegorical structure of desire, assuming "that the movement of allegory, like dream-work, enacts a wish." Fineman claims that psychoanalysis itself is not only the "critical response to allegory ... but the extension and conclusion of the classic allegorical tradition from which it derives." ${ }^{106}$ This assumption has various ramifications of interest for the current project. It supports the initial argument that allegories, as images or gendered rhetorical figures, need to be seen as instances of "other speech." Their dreamlike or non-verbal figurative language reminds of, highlights, and re-enacts a dynamic of repression - and regression - that emerged in antiquity. The invention of a male public sphere and its concomitant legal system and dialectic metaphysics that denied women subject status was crucial for these forms of "other speech" to emerge. In psychoanalytic language, allegories function as prime objects of desire insofar as they represent the re-emergence of the repressed or the excluded. In Fineman's view, psychoanalysis is based on the decoding of allegories and on the production of allegorical knowledge in return.

Of course, it is well known that Freud, followed by Lacan, was never seriously interested in the kind of maternal imagery presently under investigation. Despite the fact that he surrounded himself with ancient artifacts such as Isis Nursing Horus, he invented, i.e., named and defined, the Oedipus complex as formative of modern subjectivity. ${ }^{107}$ In Freud's reading of Sophocles's tragedy, disaster ensues because of Oedipus's unintended violation of an incest taboo. Oedipus's downfall is seen as symbolic of the castration anxiety children experience when fantasizing about violating their father's prohibition of continued, and unmediated, access to the mother. However, Oedipus himself never enjoyed such mother-child intimacy in the nursing stage from which Freud's and Lacan's patients may have needed to be weaned. After being abandoned by his birthmother, a shepherd took him to Corinth, where King Polybius and Queen Merope became his foster parents. Since Merope was childless, she most certainly employed a wet-nurse to raise him. Oedipus would have never dreamed of violating the taboo against mixing milk with blood, i.e., sleeping with his nurse. ${ }^{108}$ Likewise, there is no mention of him having erotic interest in his foster mother. The taboo he did transgress - inadvertently - supported a new order he was not familiar with: the emerging law of the father that singled out the birthmother and her offspring as constitutive of family relations based 
on the fiction of paternal "blood." Oedipus's story is shocking because of the severity of his punishment rather than the danger of his transgression: sex with one's "biological" mother who abandoned her infant at birth. Only from the point of view of a thoroughly patriarchal culture such as Sophocles's Athens or Freud's Vienna could this "crime” be interpreted as a violation that engendered chaos and anarchy and as the construction of a universally valid economy of desire based on a parricidal death-wish, respectively.

Approaching the myth from the perspective of Oedipus's unknown nurse is useful, because a focus on milk-kinship renders concrete the many critiques that feminists have waged against Freud's interpretation of the story. Especially poignant are Griselda Pollock and Bracha Ettinger in their efforts to propose the sacred, the visual, and the maternal as alternatives to Freud's and Lacan's phallo-centric systems of signification. ${ }^{109}$ In Pollock's language, the allegory of Charity seems to be exactly what Lacan's law of the father aims to suppress: "In this model, the initial dyad of Other and Child, Mother and Child in which the Mother includes all Others and carers, yields under the Father's Law. His name (nom) / prohibition (non) denies the Mother to the Child: the incest taboo."110 My contention is that such "yielding" to the law of the father refers to a long and complicated historical process that was by no means linear. Medieval and Renaissance lactation imagery suggests that during this time, proposals of alternative models of kinship, signification, and belonging were quite numerous, amounting to a whole agenda of criticizing patriarchal law and politics. Among art historians, Patricia Simons has called most convincingly for a historicization of Lacanian concepts, laying out in great detail how the Renaissance phallus differed from its modern counterpart by incorporating associations with fertility, and focusing on ejaculation rather than erection. ${ }^{111}$ I would like to go beyond her study by proposing the lactating breast as a powerful signifier of desire in its own right, arguing against recent notions of the Renaissance breast as metonymically always pointing to "something else" - the vagina - and remaining firmly ensconced within a phallic erotic economy. ${ }^{112}$ In my eyes, allegories of Charity, the Madonna Lactans, and surrounding lactation imagery, including the iconography of Pero and Cimon, celebrate milk sharing in distinction and opposition to paternal models of blood transfer. 


\section{NOTES}

1 | Sextus Pompeius Festus, De verborum significatu, livres I et II, ed. and transl. by Savagner (Paris: Panckoucke, 1846); http://remacle.org/bloodwolf/erudits/Festus/p. htm; [accessed 4/23/13].

2 | See, for example: Kourotrophos, Cypriot, 3rd quarter of 6th century BCE, New York, Metropolitan Museum of Art, inv. no. 74.51.2526. Stephanie Lynn Budin, Images of Woman and Child from the Bronze Age: Reconsidering Fertility, Maternity, and Gender in the Ancient World (Cambridge: Cambridge University Press, 2011).

3 | Theodora Hadzisteliou Price, Kourotrophos: Cults and Representations of the Greek Nursing Deities (Leiden: Brill, 1978), 199-212, especially 202.

4 | Apollodorus' Library and Hyginus' Fabulae: Two Handbooks of Greek Mythology, ed. and transl. by R. Scott Smith and Stephen M. Trzaskoma (Indianapolis: Hackett Publishing Company, Inc., 2007), 174.

5 | Isis Nursing Horus, Egyptian, 664-630 BCE, New York, Metropolitan Museum of Art, inv. no. 23.6.9. Price, Kourotrophos, 212.

6 | Waldemar Deonna, "La légende de Pero et de Micon et l'allaitement symbolique," Latomus 13 (1954): 140-66; 356-75; Larissa Bonfante, "Nursing Mothers in Classical Art," in: Naked Truths: Women, Sexuality, and Gender in Classical Art and Archaeology, ed. by Ann Olga Koloski-Ostrow and Claire L. Lyons (New York: Routledge, 1997), 174-96, especially 180.

7 | Bonfante, "Nursing Mothers in Classical Art," 184-85. Patrizia Birchler Emery, "De la nourrice à la dame de compagnie: le cas de la trophos en Grèce antique," Paedagogica Historica 46, no. 6 (2010): 751-61.

8 | Ioli Kalavrezou, "Images of the Mother: When the Virgin became the 'Meter Theou," Dumbarton Oaks Papers 44 (1990): 165-72, especially 166.

9 | Geri Parlby, "The Origins of Marian Art: The Evolution of Marian Imagery in the Western Church until AD 431," in: Mary: The Complete Resource, ed. by Sarah Jane Boss (Oxford: Oxford University Press, 2007), 106-29, especially 111-14.

10 | Parlby, "The Origins of Marian Art," 111-14.

11 Madonna Lactans, 2nd century CE, Rome, Catacombs of Priscilla. Kalavrezou, "Images of the Mother," 165.

12 | Bonfante, "Nursing Mothers in Classical Art," 184.

13 | Kalavrezou, "Images of the Mother."

14 Alfredo Tradigo, Icons and Saints of the Eastern Orthodox Church, transl. by Stephen Sartarelli (Los Angeles: J.P. Getty Museum, 2006), 183.

15 | I would like to thank Matteo Casini for this reference.

16 Miri Rubin, Mother of God: A History of the Virgin Mary (New Haven: Yale University Press, 2009), 40-42, 63-66, 211-16.

17 | Gianna Pomata, "Legami di sangue, legami di seme: consanguinità e agnazione nel diritto romano," Quaderni Storici 86, no. 2 (1994): 299-334.

18 Quoted in James J. Paxson, The Poetics of Personification (Cambridge: Cambridge University Press, 1994), 12. 
19 | Demetrius of Phalerum, On Style, 365. Quoted in Theresa M. Kelley, Reinventing Allegory (Cambridge, Massachusetts: Harvard University Press, 1997), 18.

20 | Kelley, Reinventing Allegory, 17.

21 | Kelley, Reinventing Allegory, 5.

22 | Paxson, The Poetics of Personification, 18, 19.

23 | Anon., Rhetorica Ad Herennium, IV, 66; quoted in: Paxson, The Poetics of Personification, 13-14.

24 | Kelley, Reinventing Allegory, 20-21.

25 | Kelley, Reinventing Allegory, 22.

26 | Valerius Maximus, Memorable Doings and Sayings, ed. and transl. by D.R. Shackleton Bailey (Cambridge, Massachusetts: Harvard University Press, 2000), vol. I, V.4. ext. 1, 501-03.

27 | Maureen Quilligan, The Language of Allegory: Defining the Genre (Ithaca; London: Cornell University Press, 1979), 31.

28 Erich Auerbach, Scenes from the Drama of European Literature (Theory and History of Literature, vol. 9) (Manchester: Manchester University Press, 1984; first ed. 1959), 38.

29 | Tintoretto, Moses Striking the Rock, 1577, Venice, Scuola Grande di San Rocco; Tintoretto, Elisha Multiplying the Bread, 1577-78, Venice, Scuola Grande di San Rocco; Tintoretto, The Baptism of Christ, 1581, Venice, Scuola Grande di San Rocco; Tintoretto, The Multiplication of the Loaves and Fishes, Venice, Scuola Grande di San Rocco.

30 | Jutta Sperling, "Allegories of Charity and the Practice of Poor Relief at the Scuola Grande di San Rocco," Wallraf-Richartz-Jahrbuch 70 (2009): 119-46.

31 | Jutta Sperling, "Charity's Nudity and the Veil of Allegory," in: Renaissance Studies in Honor of Joseph Connors, ed. by Machtelt Israëls and Louis A. Waldman (Milan: Officina Libraria; Cambridge, Massachusetts: Harvard University Press, 2013), vol. I, 520-26.

32 | I am referring here to Jacques Derrida's and Luce Irigaray's critique of Western philosophy as based on binary oppositions, exclusions, and hierarchies, a view they elaborated by critically appropriating Lacan's theory of the phallus as main signifier in language.

33 | See the work of Thomas Laqueur and his critics: Thomas Laqueur, Making Sex: Body and Gender from the Greeks to Freud (Cambridge, Massachusetts: Harvard University Press, 1990); Katharine Park and Lorraine Daston, "Destiny is Anatomy," review of Thomas Laqueur, Making Sex: Body and Gender from the Greeks to Freud (1990), The New Republic (18 February 1991): 53-57; Katharine Park, "Itineraries of the 'One-SexBody': A History of an Idea," unpublished manuscript; Jane Fair Bestor, "Ideas about Procreation and Their Influence on Ancient and Medieval Views of Kinship," in: The Family in Italy from Antiquity to the Present, ed. by David I. Kertzer and Richard P. Saller (New Haven: Yale University Press, 1991), 150-67; Joan Cadden, Meanings of Sex Difference in the Middle Ages: Medicine, Science, and Culture (Cambridge: Cambridge 
University Press, 1993), Helen King, The One-Sex Body on Trial: The Classical and Early Modern Evidence (Farnham, Surrey; Burlington, Vermont: Ashgate, 2013).

34 | On Plato's Timaeus and Luce Irigaray's critique, see Judith Butler, "The Lesbian Phallus and the Morphological Imaginary," in: Judith Butler, Bodies That Matter: On the Discursive Limits of Sex (New York: Routledge, 1993), 27-55. See also Luce Irigaray's critique of Plotin. Luce Irigaray, "Eine Mutter aus spiegelndem Eis," in: Speculum: Spiegel des anderen Geschlechts (Frankfurt a.M.: Suhrkamp, 1980; first French ed. 1974); see also Plotin, “Die Affektionsfreiheit des Unkörperlichen,” in: Schriften, ed. by Richard Harder, Willy Theiler, and Rudolf Beutler (Hamburg: Felix Meiner, 1962), vol. II, 218-25.

35 | John Sallis, Chorology: On Beginning in Plato's Timaeus (Bloomington: Indiana University Press, 1999), 98-99, 110-11.

36 | Gianna Pomata, "Blood Ties and Semen Ties: Consanguinity and Agnation in Roman Law," in: Gender, Kinship, Power: a Comparative and Interdisciplinary History, ed. by Mary Jo Maynes, Ann Waltner, Birgitte Soland, and Ulrike Strasser (New York: Routledge, 1996), 43-64; Bestor, "Ideas about Procreation."

37 | Deonna, "La légende de Pero et de Micon."

38 According to Peter Parkes, fosterage and wet-nursing practices established rival family systems in Ireland, the Balkans, and the Mughal Empire, complementing, and sometimes even supplanting, paternal "blood" bonds. Peter Parkes, "Alternative Social Structures and Foster Relations in the Hindu Kush: Milk Kinship Allegiance in Former Mountain Kingdoms of Northern Pakistan," Comparative Studies in History and Society 43, no. 1 (2001): 4-36; idem, "Fostering Fealty: A Comparative Analysis of Tributary Allegiances of Adoptive Kinship," Comparative Studies in Society and History 45, no. 4 (2003): 741-82; idem, "Fosterage, Kinship, and Legend: When Milk Was Thicker Than Blood?" Comparative Studies in Society and History 46, no. 3 (2004): 587-615. To this day, milk-kinship as defined by Islamic law establishes powerful incest taboos that mirror those of birth families. Parkes, "Alternative Social Structures;" Avner Giladi, Infants, Parents, and Wet Nurses: Medieval Islamic Views on Breastfeeding and Their Social Implications (Leiden: Brill, 1999); Hocine Benkheira, “'The Milk of the Male': Kinship, Maternity and Breastfeeding in Medieval Islam," in: Medieval and Renaissance Lactations: Images, Rhetorics, Practices, ed. by Jutta Gisela Sperling (Aldershot, England; Burlington, Vermont: Ashgate, 2013), 21-36.

39 | Caritas becomes "piety's" heiress also because of both virtues' antagonistic relationship to "justice." If Pero remains victorious over the Roman court system by achieving her father's release from prison, Charity is seen as complementing Justice, swords raised, on fifteenth-century decorations of the Ducal Palace in Venice. Bartolomeo Bon, Charity, 1438-41, Venice, Ducal Palace, Porta della Carta. David Rosand, Painting in Cinquecento Venice: Titian, Veronese, Tintoretto (Cambridge: Cambridge University Press, 1997), 127; Anne Markham Schulz, The Sculpture of Giovanni and Bartolomeo Bon and Their Workshop (Transactions of the American Philosophical Society 68, no. 3) (Philadelphia: American Philosophical Society, 1978), 33, 39. 
40 | Robert Freyhan, "The Evolution of the Caritas Figure in the Thirteenth and Fourteenth Centuries," Journal of the Warburg and Courtauld Institutes 11 (1948): 68-86; on the afterlife of cornucopia-bearing women as dovizie, see Adrian W.B. Randolph, Engaging Symbols: Gender, Politics, and Public Art in Fifteenth-Century Florence (New Haven: Yale University Press, 2002), 29, 40.

41 | Tino da Camaino, Charity, ca. 1321, Florence, Museo Bardino.

42 | Giovanni di Balduccio, Charity, ca. 1330, Washington, National Gallery, Samuel H. Kress Collection, inv. no. 1960.5.4.

43 | Beth Williamson, The Madonna of Humility: Development, Dissemination \& Reception, ca. 1340-1400 (Woodbridge: The Boydell Press, 2009), 115-18.

44 | Max Seidel, "Ubera Matris: Die vielschichtige Bedeutung eines Symbols in der mittelalterlichen Kunst," Städel-Jahrbuch 6, Neue Folge (1977): 41-99, especially 68.

45 | Seidel, “Ubera matris," 61.

46 | Joel Fineman, "The Structure of Allegorical Desire," October 12 (Spring 1980): 46-66, especially 48.

47 | Quoted in Seidel, "Ubera matris," 75. Caroline W. Bynum reports that when Mechthild asked Christ why he bled after he had died, Christ answered: "The blood issued forth by grace, just as did the milk that I drank from my virginal mother." Caroline W. Bynum, Wonderful Blood: Theology and Practice in Late Medieval Northern Germany and Beyond (Philadelphia: University of Pennsylvania Press, 2007), 164.

48 | Lorenzo Monaco, The Intercession of Christ and the Virgin, before 1402, New York, Metropolitan Museum of Art, inv. no. 53.37.

49 | "For Christ, in his humility, is our milk." William of Saint Thierry, Exposition on the Song of Songs, transl. by Columba Hart (Spencer, Massachusetts: Cistercian Publications, 1970), I.46, 36; quoted in: Thomas of Cantimpré, The Collected Saints' Lives: Abbot John of Cantimpré, Christina the Astonishing, Margaret of Ypres, and Lutgard of Aywières, ed. and introduced by Barbara Newman; transl. by Margot $\mathrm{H}$. King and Barbara Newman (Turnhout: Brepols, 2008), 132, note 12.

50 | Daniel Cramer, Zehen Catechismus Predigten. Das ist: Die Vernunftige Lautere Milch Des H. Catechismus Lutheri öffentlich gehalten und nunmehr zum andern mahl in truck geben durch Danielem Cramerum der H. Schrift Doctorem Pastoren der Stiffts Kirchen und Professoren des Furstlichen Pedagogij zu alten Stettin (Alt-Stettin: David Rehten, 1635), no pagination.

51 | Giovanni Thiepolo Primicerio di San Marco, Trattato delle santissime reliquie, ultimamente ritrovate nel Santuario della Chiesa di San Marco (Venice: appresso Antonio Pinelli, 1618), 43-45.

52 | Desiderius Erasmus, “A Pilgrimage for Religion's Sake," in: The Colloquies of Erasmus, transl. by N. Bailey, ed. by the Rev. E. Johnson (London: Reeves and Turner, 1878), vol. 2, 1-37, here p. 5; http://If-oll.s3.amazonaws.com/titles/726/0046-02_ Bk.pdf; [accessed 5/6/14]. I would like to thank Kenneth Gouwens for having mentioned this text to me. For the identification of Glaucoplutus, the recipient of Mary's letter, as Ulrich Zwingli, see Hilmar M. Pabel, Conversing with God: Prayer in Erasmus' 
Pastoral Writings (Toronto: University of Toronto Press, 1997), 84; http://books. google.de/books?id=mPLyQnOWVewC\&pg=PA84\&lpg=PA84\&dq=glaucoplutus\&sour$c e=b \mid \& o t s=h u C k A T I n 0 n \& s i g=9 g 1 P k g V w T h Y p \_E 5 a y 7 d J w N 1 F e g Y \& h l=e n \& s a=X \& e i=f P-$ FoU9bYF8_7yA08jlGwCw\&ved=0CC8Q6AEwAg\#v=onepage \& $q=$ glaucoplutus $\& f=$ false; [accessed 5/6/14].

53 | Erasmus, "A Pilgrimage for Religion's Sake," 19; http://If-oll.s3.amazonaws.com/ titles/726/0046-02_Bk.pdf [accessed 5/6/14].

54 | Caroline W. Bynum, Holy Feast and Holy Fast: The Religious Significance of Food to Medieval Women (Berkeley; Los Angeles: University of California Press, 1987).

55 | "When she turned her eyes to herself, she immediately saw that the dry paps of her virginal breasts were dripping sweet milk against the very law of nature." Cantimpré, The Collected Saints' Lives, 132.

56 | Bynum, Holy Feast and Holy Fast, 118-23.

57 | Gianna Pomata, "A Christian Utopia of the Renaissance: Elena Duglioli's Spiritual and Physical Motherhood (ca. 1510-1520)," in: Von der dargestellten Person zum erinnerten Ich: Europäische Selbstzeugnisse als historische Quellen (1500-1850), ed. by Kaspar von Greyerz, Hans Medick, and Patrice Veit (Köln: Böhlau, 2001), 323-53, especially 334.

58 Raymond of Capua, The Life of Catherine of Siena, translated, introduced and annotated by Conleth Kearns; preface by Vincent de Couesnongle (Wilmington, Del.: Glazier, 1980), 180, 183, 189.

59 | Raymond of Capua, The Life of Catherine of Siena, 156.

60 | According to Gauthier de Coincy (1177-1236), Abbot of the monastery of Saint Médard in Soissons, the lactating Virgin Mary cured one of his monks from a potentially lethal episode of inexplicable weakness. Margaret R. Miles, "The Virgin's One Bare Breast: Female Nudity and Religious Meaning in Tuscan Early Renaissance Culture," in: The Female Body in Western Culture: Contemporary Perspectives, ed. by Susan Rubin Suleiman (Cambridge, Massachusetts: Harvard University Press, 1986), 193-208. L'allégorie dans la peinture: l'allégorie de la charité au XVIle siècle, ed. by Alain Tapié, Caroline Joubert, Jennifer Montague, and Grisèle Jouet (Caen: Musée des Beaux-Arts de Caen, 1986), 34-35. Caroline W. Bynum, "Jesus as Mother and Abbot as Mother: Some Themes in Twelfth-Century Cistercian Writings," Harvard Theological Review 70, nos. 3-4 (1977): 257-84.

61 "Madonna Clare herself used to tell how once in a vision it seemed to her that she was carrying a basin of ... water to Saint Francis, with a towel for drying hands, and she was going up a staircase but with so light a step as if she were walking on flat ground. And having reached the Saint he bared his breast and told the virgin Clare: 'Come, receive and suck' ... And after she suckled, the round mouth of the breast whereof the milk had flowed stayed between her lips and she took it in her hands and looked at it, and it was as bright and shining as gold, so that she saw all of herself reflected in it as in a mirror." Quoted in: Pomata, "A Christian Utopia of the Renaissance," 333, note 32 . 
62 Helga Kraft, “Töchter, die keine Muetter werden: Nonnen, Amazonen, Mätressen. Hildegard von Bingen, Mechthild von Magdeburg, Grimmelshausens Courasche, Lessings Marwood in Miss Sara Simpson," in: Mütter - Töchter - Frauen: Weiblichkeitsbilder in der Literatur, ed. by Helga Kraft and Elke Liebs (Stuttgart; Weimar: Verlag J.B. Metzler, 1993), 35-52, Figure 3. Unfortunately, Kraft does not give any information about the origin and whereabouts of this illumination.

63 | Jo Ann McNamara, "The Need to Give: Suffering and Female Sanctity in the Middle Ages," in: Images of Sainthood in Medieval Europe, ed. by Renate Blumenfeld-Kosinski and Timea Szell (Ithaca: Cornell University Press, 1991), 199-221; Sperling, "Allegories of Charity."

64 | "There is ... little evidence that women identified with the Virgin's power." Miles, “The Virgin's One Bare Breast," 205. See also idem, A Complex Delight: The Secularization of the Breast 1350-1750 (Berkeley; Los Angeles: University of California Press, 2008), in which Miles expands her earlier arguments.

65 | Miles, “The Virgin's One Bare Breast," 206.

66 | "Only the blessed Virgin Mary has done more for God, or just as much, as God has done for all humankind." Miles, "The Virgin's One Bare Breast," 202.

67 | Clarissa W. Atkinson, The Oldest Vocation: Christian Motherhood in the Middle Ages (Ithaca: Cornell University Press, 1991); Rosemary Drage Hale, "Imitatio Mariae: Motherhood Motifs in Late Medieval German Spirituality," (Ph.D. thesis, Harvard University, 1992).

68 | Naomi Yavneh, “To Bare or Not Too Bare: Sofonisba Anguissola's Nursing Madonna and the Womanly Art of Breastfeeding," in: Maternal Measures: Figuring Caregiving in the Early Modern Period, ed. by Naomi J. Miller and Naomi Yavneh (Aldershot, England; Burlington, Vermont: Ashgate, 2000), 65-81, especially 69; Charlene Villaseñor Black, "The Moralized Breast in Early Modern Spain," in: The Material Culture of Sex, Procreation, and Marriage in Premodern Europe, ed. by Anne L. McClanan and Karen Rosoff Encarnacion (New York: Palgrave 2002), 191-219, especially 192.

69 | Megan Holmes, "Disrobing the Virgin: The Madonna Lactans in Fifteenth-Century Florentine Art," in: Picturing Women in Renaissance and Baroque Italy, ed. by Geraldine A. Johnson and Sara F. Matthews Grieco (Cambridge: Cambridge University Press, 1997), 167-95.

70 | Pomata, “A Christian Utopia of the Renaissance," 334.

71 | Pomata, "A Christian Utopia of the Renaissance," 343.

72 | Pomata, "A Christian Utopia of the Renaissance," 335-36.

73 "And it is very true that if the nipple is touched, it immediately raises like the virga [penis]; and thus because of the connection of uterus and penis with the breasts, these organs are aroused, especially in those who are already prepared and ready for coition." Quoted in: G. Pomata, “A Christian Utopia of the Renaissance," 348-49. See also Katharine Park, Secrets of Women: Gender, Generation, and the Origins of Human Dissection (New York: Zone Books; distributed by Cambridge, Massachusetts: MIT Press, 2006), 168. 
74 | Park, Secrets of Women, 176.

75 | On representations of the breast in Renaissance art, see Marilyn Yalom, A History of the Breast (New York: Alfred A. Knopf, 1997).

76 | Miles, "The Virgin's One Bare Breast."

77 | Andrea Guardi, Charity, 1452, Pisa, Santa Maria della Spina, Choir Relief, now in National Museum of San Matteo.

78 | Filippino Lippi, Charity, 1487-1502, Florence, Santa Maria Novella, Capella Strozzi.

79 | See the paintings by Domenico Ghirlandaio and workshop (ca. 1490) and Cosimo Rosselli (1492). Holmes, "Disrobing the Virgin," 180-81.

$\mathbf{8 0} \mid$ Holmes, "Disrobing the Virgin," 183.

81 For the allegorical and political significance of Bartolo's frescoes, see Diana Bullen Presciutti, “Picturing Institutional Wet Nursing in Medicean Siena," in: Sperling, Medieval and Renaissance Lactations, 129-46; see also idem, "Carità e potere: Representing the Medici Grand Dukes as 'Fathers of the Innocenti," Renaissance Studies 24, no. 2 (2010): 234-59.

82 Patricia Simons, "The Social and Religious Context of Iconographic Oddity: Breastfeeding in Ghirlandaio's Birth of the Baptist," in: Sperling, Medieval and Renaissance Lactations, 213-34.

83 | On the civic importance of Florentine "dovizie," i.e., figures of abundance and generosity, see Adrian Randolph, Engaging Symbols.

84 | On Tintoretto's paintings of The Birth of Saint John the Baptist, see Jutta Gisela Sperling, “Wet Nurses, Midwives, and the Virgin Mary in Tintoretto's Birth of Saint John the Baptist (1563)," in: Medieval and Renaissance Lactations, 235-54.

85 | On confinement room scenes, see Jacqueline Marie Musacchio, The Art and Ritual of Childbirth in Renaissance Italy (Princeton: Princeton University Press, 1999).

86 | Gunter Schweikhart, "Antikenkopie und -verwandlung im Fries des Marcello Fogolino aus der Villa Trissino-Muttoni (Ca' Impenta) bei Vicenza. Ein Beitrag zur Geschichte der Villendekoration des frühen 16. Jahrhunderts im Veneto," Mitteilungen des kunsthistorischen Institutes in Florenz 20, no. 3 (1976): 351-78, especially 358-60.

87 Ernest Phillipe Alphonse Law, A Historical Catalogue of the Pictures in the Royal Collection at Hampton Court (London: G. Bell and Sons, 1881), 96, entry 305.

88 | Giovanni Maria Falconetto, Archaeological Landscape, before 1535, Mantua, Palazzo d'Arco, Sala dello Zodiaco.

89 | Giulio Romano, exhibition catalog, Palazzo Te, Mantua, September 1-November 12, 1989, ed. by Ernst Gombrich et al. (Milan: Electa, 1989), 308. On polymast figures denoting abundance and excess in sixteenth-century French art, see Rebecca Zorach, Blood, Milk, Ink, Gold: Abundance and Excess in the French Renaissance (Chicago: University of Chicago Press, 2005).

90 | See also H.R. Rookmaker, “'Charity' in Seventeenth Century Art," Nederlands Kunsthistorisch Jaarboek 23 (1972): 61-66. 
91 | Tiziano e la silografia Veneziana del cinquecento, exhibition catalog, Fondazione Giorgio Cini, 1976, ed. by Michelangelo Muraro and David Rosand (Vicenza, N. Pozza, 1976) Scheda 8-B. My thanks to Monika Schmitter, who mentioned this image to me.

92 | La pittura nel Veneto: II Cinquecento, ed. by Mauro Lucco et al. (Milan: Electa, 1996-), vol. 1, 173, Figure 218. This image was mentioned to me by Monika Schmitter as well.

93 | Tintoretto, Saint Mark Freeing the Slave, 1548, Venice, Galleria dell'Accademia.

94 | Tintoretto, The Miracle of the Loaves and Fishes, 1545-50, New York, Metropolitan Museum of Art, inv. no. 13.75.

95 | Jacopo Tintoretto, Le opere sacre e profane, ed. by Rodolfo Pallucchini and Paola Rossi (Milan: Alfieri, Gruppo Editoriale Electa, 1982), 2 vols. Diana Bullen Presciutti mentions a wet-nurse who represents one of the seven works of mercy, namely, "Feeding the Hungry," in a fifteenth-century fresco in the church of San Fiorenzo in the Piedmontese town of Bastia Mondovi. Presciutti, "Picturing Institutional Wet-Nursing," 140 , note 27.

96 | Tintoretto, Moses Striking the Rock, 1577, Venice, Scuola Grande di San Rocco.

97 | Tintoretto, The Baptism of Christ, 1581, Venice, Scuola Grande di San Rocco; J. Sperling, "Allegories of Charity."

98 | Pietas e allattamento filiale: La vicenda - l'exemplum - l'iconografia; colloquio di Urbino, 2-3 maggio, 1996, ed. by Renato Raffaelli, Roberto M. Danese, and Settimio Lanciotti (Urbino: Quattro Venti, 1997), Figure VIII.1.

99 | Raffaelli et al., Pietas e allattamento filiale, Figure VIII.2.

100 | Allegorie, Philosophie, Sages, in: Boethius, De consolatione philosophiae (1491), BN, Paris, Néerlandais 1, f. 12v. On Pisano, see Seidel, “Ubera Matris," 50-51. 101 | Giovanni Boccaccio, De Claris Mulieribus, transl. by Heinrich Steinhöwel, ed. by Karl Drescher (Tübingen: Litterarischer Verein Stuttgart, 1895; first German edition UIm: Johann Zainer, 1473), 215-16.

102 | Jahrbuch der Kunsthistorischen Sammlungen des Allerhöchsten Kaiserhauses 2 (1885), plate VIII; Die Italienischen Bronzen der Renaissance und des Barock, part II, Reliefs und Plaketten, ed. by E.F. Bange (Berlin: G. Reimer, 1922), 126, no. 959, plate 78; Albert Fidelis Butsch, Handbook of Renaissance Ornament; 1290 designs from decorated books, with a new introduction and captions by Alfred Werner (New York: Dover Publications, 1969), plate 130; Denis Mahon and Nicholas Turner, The Drawings of Guercino in the Collection of her Majesty the Queen at Windsor Castle (Cambridge: Cambridge University Press, 1989), f. 184.

103 | Andor Pigler, Barockthemen: eine Auswahl von Verzeichnissen zur Ikonographie des 17. und 18. Jahrhunderts (Budapest: Akadémiai Kiadó, 1974; first ed. Budapest: Verlag der Ungarischen Akademie der Wissenschaften, 1956), vol. 2, 297.

104 | Tintoretto, The Creation of the Milky Way, 1575-80, London, National Gallery, inv. no. 1313.

105 | On Veronese, see Gianna Pomata, unpublished paper; on Rubens, see Lisa Rosenthal, Gender, Politics, and Allegory in the Art of Rubens (Cambridge: Cambridge 
University Press, 2005), 48-60; see also Lisa Rosenthal, "Venus's Milk and the Temptations of Allegory in Otto Van Veen's Allegory of Temptation," in: Early Modern Visual Allegory: Embodying Meaning, ed. by Cristelle Baskins and Lisa Rosenthal (Aldershot, England; Burlington, Vermont: Ashgate, 2007), 219-42.

106 | Fineman, "The Structure of Allegorical Desire," 46.

107 | Griselda Pollock, “The Object's Gaze in the Freudian Museum," in: Griselda Pollock, Encounters in the Virtual Feminist Museum: Time, Space, and the Archive (New York: Routledge, 2007), 67-86, especially 72.

108 | See also Marianne Novy, Reading Adoption: Family and Difference in Fiction and Drama (Ann Arbor: University of Michigan Press, 2005), 37-55.

109 | Griselda Pollock, “Woman as Sign: Psychoanalytic Readings," in: Griselda Pollock, Vision and Difference: Femininity, Feminism and Histories of Art (New York: Routledge, 1988), 120-54; idem, "What the Graces made me do ... Time, Space and the Archive: questions of feminist method," in: Pollock, Encounters in the Virtual Feminist Museum, 9-38; Bracha Lichtenberg Ettinger, "Matrix and Metramorphosis," Differences: A Journal of Feminist Cultural Studies 4, no.3 (1992): 176-206.

110 | Griselda Pollock and Victoria Turvey Sauron, The Sacred and the Feminine: Imagination and Sexual Difference (New York: Palgrave Macmillan, 2007), 39.

111 Patricia Simons, The Sex of Men in Premodern Europe: A Cultural History (Cambridge: Cambridge University Press, 2011).

112 | Zorach, Blood, Milk, Ink, Gold, 123. 